\title{
Membrane-Interacting Antifungal Peptides
}

\author{
Caroline Struyfs, Bruno P. A. Cammue and Karin Thevissen* \\ Centre of Microbial and Plant Genetics, KU Leuven, Leuven, Belgium
}

The incidence of invasive fungal infections is increasing worldwide, resulting in more than 1.6 million deaths every year. Due to growing antifungal drug resistance and the limited number of currently used antimycotics, there is a clear need for novel antifungal strategies. In this context, great potential is attributed to antimicrobial peptides (AMPs) that are part of the innate immune system of organisms. These peptides are known for their broad-spectrum activity that can be directed toward bacteria, fungi, viruses, and/or even cancer cells. Some AMPs act via rapid physical disruption of microbial cell membranes at high concentrations causing cell leakage and cell death. However, more complex mechanisms are also observed, such as interaction with specific lipids,

OPEN ACCESS

Edited by:

Patrick Rockenfeller, Universität Witten Herdecke, Germany

Reviewed by: Marilyn Anderson, La Trobe University, Australia Florentine Marx, Medical University of Innsbruck, Austria

*Correspondence: Karin Thevissen

karin.thevissen@kuleuven.be; karin.thevissen@biw.kuleuven.be

Specialty section:

This article was submitted to

Membrane Traffic,

a section of the journal Frontiers in Cell and Developmental Biology

Received: 05 January 2021 Accepted: 09 March 2021 Published: 12 April 2021

Citation:

Struyfs C, Cammue BPA and Thevissen K (2021) Membrane-Interacting Antifungal Peptides. Front. Cell Dev. Biol. 9:649875. doi: 10.3389/fcell.2021.649875 production of reactive oxygen species, programmed cell death, and autophagy. This review summarizes the structure and mode of action of antifungal AMPs, thereby focusing on their interaction with fungal membranes.

Keywords: antimicrobial peptides, mode of action, antifungal activity, membrane-interaction, review

\section{INTRODUCTION}

In the past two decades, fungal infections have caused severe die-offs and extinctions in wild species, as they comprise the biggest threat for both plant (64\%) and animal (72\%) species in terms of infection-related species extinctions (Fisher et al., 2012). Moreover, fungal infections are also jeopardizing food security, as they are causing both yield and post-harvest losses (Fisher et al., 2012; Gauthier and Keller, 2013).

In human health, invasive fungal infections (IFIs) are yearly causing 1.6 million deaths worldwide (Fisher et al., 2020). This number is still increasing (i) due to a rise in the number of immunocompromised patients, e.g., patients receiving immunosuppressive therapies in context of cancer treatment or transplantation (Kim, 2016; Bongomin et al., 2017), and (ii) due to an increased use of modern medical devices, such as catheters and implants (Kojic and Darouiche, 2004; Vandecandelaere and Coenye, 2015). Notably, the number of IFI deaths is most likely an underestimation due to poor epidemiological data and misdiagnosis (Bongomin et al., 2017; Spitzer et al., 2017; Benedict et al., 2019). Currently, only three main classes of antifungal drugs are available, namely azoles, polyenes and echinocandins, while antifungal drug resistance is increasing (Fisher et al., 2018; Revie et al., 2018). Candida spp. and Aspergillus spp. are mainly responsible for IFI with mortality rates up to 50\% (Brown et al., 2012; Bongomin et al., 2017). Moreover, the recently identified pathogen Candida auris is often multidrug resistant, with some strains resistant to all three available antifungal classes (Lockhart et al., 2017). In addition, both the Centers for Disease Control and Prevention and the World Health Organization recently placed fungal pathogens on their concern list (Centers for Disease Control and Prevention [CDC], 2019; World Health Organization [WHO], 2020). Hence, there is a clear need for novel antifungal strategies. 
Antimicrobial peptides (AMPs) are host defense peptides of the nonspecific innate immune system that are part of the first line of immune defense (Hancock and Patrzykat, 2002; Teixeira et al., 2012; Shah et al., 2016, 2019; Contreras et al., 2019). Due to their broad-spectrum activity, selective targeting, multiple modes of action and often limited toxicity to human cells, great potential is attributed to AMPs. AMPs were first described in 1939 by Dubos, who isolated gramicidin from Bacillus brevis (Dubos, 1939). Later in the 1980s, cecropins, defensins and magainins were isolated from moths, human neutrophils and amphibians, respectively (Steiner et al., 1981; Ganz et al., 1985; Zasloff, 1987). Currently, over 3000 AMPs are described in the Antimicrobial Peptide Database (Wang et al., 2016), nevertheless only a limited number of AMPs have been studied regarding their mechanism of action. AMPs are present in bacteria, fungi, plants, invertebrates and vertebrates (van der Weerden et al., 2013; Wang et al., 2016; Kumar et al., 2018), and are known for their broad-spectrum that can include activity against bacteria, fungi, viruses, protozoa and/or even cancer cells (Wachinger et al., 1998; do Nascimento et al., 2015; El-Mounadi et al., 2016; Cools et al., 2017a; Parvy et al., 2019; Struyfs et al., 2020). Note that individual AMPs may not act against all these organisms. Apart from their direct action, AMPs can also function indirectly via immunomodulation in higher organisms. Firstly, AMPs can affect the innate immune system, e.g., enhanced wound healing by the salivary peptides histatin 1 and 2 (Oudhoff et al., 2008). Secondly, AMPs can modulate and bridge the adaptive immune response elements, e.g., human $\beta$-defensins 1,2 , and 3 (hBD-1,2 , and -3 ) induce the upregulation of specific cytokines, such as IL- 8 and MCP-1, whereas only hBD-1,-2 induce IL- 6 and IL-10 (Boniotto et al., 2006). In animals, AMPs are mostly produced by epithelial cells of skin, airways and gastrointestinal tract (Zasloff, 2002), while in plants they preferentially accumulate in the peripheral cell layer (Broekaert et al., 1997; Lay and Anderson, 2005; van der Weerden et al., 2013; Parisi et al., 2019b). AMPs can be constitutively expressed e.g., hBD-1 in epithelial cells (O'Neil et al., 1999); termicin and spinigerin in termites (Lamberty et al., 2001b) and the plant defensin Psd1 in the epidermal tissues and vascular bundles of pea pods (Almeida et al., 2000, 2002). Additionally, AMPs can be expressed upon induction e.g., hBD-2,-3, and -4 in epithelial cells upon infection and inflammation (García et al., 2001; Liu et al., 2003; Sørensen et al., 2003; Gácser et al., 2014); CRAMP in mouse skin upon Candida albicans infection (López-García et al., 2005) and plant peptides e.g., AtPDF1.2, AtPDF2.3 in leaves upon microbial invasion (Penninckx et al., 1996; Broekaert et al., 1997; Manners et al., 1998; Thomma and Broekaert, 1998; Lay and Anderson, 2005; van der Weerden et al., 2013; Parisi et al., 2019b).

The focus of this review will be on the structure and mode of action of membrane-interacting antifungal AMPs and on a potential link between their mode of action and membrane contact sites (MCSs), thereby focusing on AMPs of which the mode of action is already described in more detail. Additional information on AMPs can be found in Faruck et al. (2016); Parisi et al. (2019b), Buda De Cesare et al. (2020), and Mookherjee et al. (2020). Gaining insight in their mechanism of action allows to exploit this information for novel therapeutics.

\section{STRUCTURE}

Antimicrobial peptides are typically composed of 12 to 54 amino acids (AA) with an overall net positive charge at physiological pH (Teixeira et al., 2012; Mookherjee et al., 2020). However, also negatively charged peptides exist, such as dermcidin (Homo sapiens) and maximin H5 (Bombina maxima) (Schittek et al., 2001; Lai et al., 2002). In general, up to $50 \%$ of the residues are hydrophobic, thereby contributing to an amphipathic conformation that enhances their interaction with the target membrane (Gomes et al., 2018). AMPs are known for their sequence diversity and wide range of secondary structures. Based on their conformation four main groups can be distinguished, i.e., (i) $\alpha$-helical peptides, (ii) $\beta$-sheet peptides with disulfide bridges, (iii) cyclic peptides, and (iv) residue-rich peptides. Firstly, $\alpha$-helical peptides are usually unstructured in aqueous solvent, whereas in the presence of membranes, they fold into amphiphilic $\alpha$-helices in which polar and non-polar AA are segregated along the helical axis (Almeida and Pokorny, 2012; Hollmann et al., 2018). The size of $\alpha$-helical peptides ranges between 12 and 37 AA; they typically contain a kink or central hinge region (Tossi et al., 2000). Examples of $\alpha$-helical peptides are cathelicidins [e.g., LL-37 (human) and CRAMP (mouse)], cecropins (moths), magainins (amphibians), and melittin (honeybee) (Zasloff, 1987; Gallo et al., 1997; Silvestro et al., 2000; Andrä et al., 2001; Den Hertog et al., 2005; Park and Lee, 2010; Ordonez et al., 2014). Also $\alpha$-helical peptides with a disulfide bridge have been occasionally described. Their N-terminal region consists of an amphipathic $\alpha$-helix, whereas the $\mathrm{C}$-terminus contains a disulfide bridge (Almeida and Pokorny, 2012), such as brevinin 2 (Rana pirica) and gaegurin 1 (Rana rugosa). Secondly, $\beta$-sheet peptides with disulfide bridges are characterized by a well-defined number of $\beta$-strands that are stabilized by disulfide bonds (Hollmann et al., 2018). These peptides have no or only a few helical domains. Cysteine-containing $\beta$-sheet peptides represent a highly diverse group of peptides, mainly represented by defensins. These peptides have been found in fungi, plants, insects and vertebrates (van der Weerden et al., 2013). Defensins have a conserved motif, namely the $\gamma$-core, which is an essential structural element that is composed of two antiparallel $\beta$-sheets (Brogden, 2005; Sathoff et al., 2019). Although early work described the isolated $\gamma$-core as an active antifungal peptide, this is not reproducible for all peptides, as synthetic $\gamma$-core peptides have been tested that were not active (Sagaram et al., 2011; Sathoff et al., 2019). For plant defensins, the $\gamma$-core comprises surface loop 5 which is essential for antifungal activity (Parisi et al., 2019b). $\beta$-sheet peptides can contain two (e.g., tachyplesins and protegrins), three (e.g., mammalian defensins and insect defensins) or four disulfide bridges (e.g., drosomycin and plant defensins) (Broekaert et al., 1997; Parisi et al., 2019b). Petunia hybrida defensins 1 and 2 $(\mathrm{PhD} 1,2)$ are, so far, the only known plant defensins containing five disulfide bridges (Janssen et al., 2003). The presence of disulfide bridges in defensins assures their stability under extreme conditions, such as exposure to high temperatures or in serum, thereby, retaining their biological activity (Osborn et al., 1995; Tavares et al., 2008). Thirdly, cyclic peptides are characterized by a cyclization of the peptide backbone, such as gramicidin 
S (Bacillus brevis), daptomycin (Streptomyces roseosporus) and cyclotides, such as kalata B1 and cycloviolacins (Tam et al., 1999; Brogden, 2005; Daly et al., 2009; Almeida and Pokorny, 2012; Slazak et al., 2018). Cyclotides contain three cysteine bridges and a structural motif known as the cyclic cysteine knot, resulting in exceptional stability. Fourthly, residue-rich peptides are characterized by the predominant presence of a particular amino acid, which imposes particular constraints to their structure, such as indolicidin (tryptophan-rich), histatin (histidine-rich) and arasin 1 (proline-rich) (Helmerhorst et al., 1999; Brogden, 2005; Almeida and Pokorny, 2012; Paulsen et al., 2013).

\section{MODE OF ANTIFUNGAL ACTION OF AMPs}

Previously, it was believed that the mode of action of AMPs solely consisted of rapid physical disruption of microbial membranes causing cell death. However, numerous antifungal AMPs have a more complex mechanism of action in which they interact with the surface of fungal cells and affect intracellular targets, leading to e.g., endogenous reactive oxygen species (ROS) production, mitochondrial and vacuolar dysfunction, programmed cell death, autophagy, and cell cycle impairment as described in more detail and summarized in Supplementary Table 1.

\section{Interaction of AMPs With the Fungal Cell Surface}

In the past, the mechanism of action of AMPs was believed to be nonspecific, resulting in pore formation by barrel-stave, carpet or toroidal pore mechanisms. In these mechanisms, (i) peptides form a bundle with a central lumen in the membrane, (ii) accumulate on the bilayer surface, or (iii) insert into the membrane and induce the lipids to bend through the pore resulting in a central lumen consisting of both peptides and lipid head groups (Brogden, 2005; Lazzaro et al., 2020). For certain AMPs, this is indeed the case. For example, using synthetic lipid vesicles, the insect peptide cecropin A (Hyalophora cecropia) was demonstrated to form ion channels at low concentrations and pores at high concentrations (Silvestro et al., 2000). It remains, however, unclear whether pore formation of cecropin $\mathrm{A}$ is responsible for its antifungal activity. In bacteria, the vertebrate peptide magainin 2 (Xenopus laevis) forms pores by the toroidal pore mechanism, whereas in mammalian cells, it forms pores via the carpet mechanism (Imura et al., 2008). Also here, the mode of action on fungal cells remains unclear. Note that membrane disrupting AMPs should not be called pore formers unless there is biophysical evidence that a pore has indeed been formed, as confirmed by e.g., ion conductance and the atomic size of the pore. Nonetheless, there is currently little evidence of antifungal AMPs that form pores in vivo or in artificial membranes that closely resemble biological membranes. Nonspecific interaction of antifungal AMPs with antimicrobial membranes is thus not the sole mechanism of action (as discussed in Wilmes et al., 2011). Thevissen et al. (1997, 2000b) were the first to report the existence of specific, high-affinity binding sites for the plant defensins
HsAFP1 and DmAMP1 on Neurospora crassa hyphae, and demonstrated that binding to these sites is required for their antifungal activity.

\section{Interaction of AMPs With the Fungal Cell Membrane}

The first step in the antifungal mechanism of action is thus the interaction of AMPs with their fungal target, which can be the fungal cell membrane and/or the fungal cell wall (see section "Interaction of AMPs With the Fungal Cell Wall"). The former mainly consists of sterols, phospholipids and sphingolipids. Phospholipids are composed of a glycerol backbone coupled to two fatty acids and one polar head group. Numerous phospholipids can be distinguished based on their polar head group, such as phosphatidic acid (PA), phosphatidylcholine, phosphatidylethanolamine (PE), phosphatidylglycerol, phosphatidylserine (PS), and phosphoinositides. Note that binding affinities between AMPs and lipids are rarely measured, and can thus not be compared. Examples of AMPs that interact with PA are the plant defensins HsAFP1, MtDef4, NaD1, NaD2, and NsD7 (Figures 1, 2C,D); some of which interact also with other phospholipids like phosphatidylinositol phosphates (PIPs) and phosphatidylinositol bisphosphates $\left(\mathrm{PIP}_{2} \mathrm{~s}\right)$ (Figure 1). The RGFRRR-motif of MtDef4 was found to be of importance for the interaction with PA, as mutants devoid of this motif are characterized by reduced binding (Sagaram et al., 2013). Similarly, this motif is present within the sequence of NaD2 and AtPDF2.3 (Cools et al., 2017a). NaD2 is demonstrated to interact with PA as well as with PIPs, as evaluated using lipid overlays and lipid vesicles (Bleackley et al., 2016; Payne et al., 2016). Although lipid overlays can be useful for initial assessment of a potential peptide - lipid interaction, this technique is often unreliable due to the high lipid concentration and the lipid orientation on the strip that are not representative of in vivo membranes (Narayan and Lemmon, 2006; Payne et al., 2016). Therefore, potential interactions observed using lipid overlays must be further validated using different techniques, such as ELISA assays, lipid vesicles, structure analysis or deletion mutants of genes that are of importance for the biosynthesis of membrane lipids. It is important to note that by using specific deletion mutants for validating a peptide-membrane component interaction, one cannot distinguish between the membrane component being the genuine peptide interaction partner or only a secondary effector in modulating peptide susceptibility. Therefore, we have listed the specific validation methods that were used in this section. For AtPDF2.3 the interaction with PA has hitherto not been validated. Nevertheless, the presence of an RGFRRR-motif seems not essential for the interaction of AMPs with PA. Recently, using lipid overlays, reverse ELISA assays and lipid vesicles, Cools et al. (2017b) demonstrated the interaction of HsAFP1 with PA, in which histidine at position 32 and arginine at position 52 are important features. Additionally, HsAFP1 also binds, to a lesser extent, to various phosphatidylinositol moieties. AMPs are also able to bind different types of phospholipids to form oligomeric fibrils with different topologies. Note that these fibrils have been produced in vitro and there is currently little evidence that they are also produced in vivo. In this respect, the plant 
defensin NsD7 forms a coiled defensin-PA double helix upon interaction with $\mathrm{PA}$, in which the critical residues that enable assembly of the dimers into an oligomer are lysine at position 36 and arginine at position 39 (Kvansakul et al., 2016). NaD1 also interacts with PA, as demonstrated using lipid overlays, lipid vesicles and structure analysis. In contrast, $\mathrm{NaD} 1$ and PA form a near-flat, carpet-like oligomeric complex in vitro during the initial stages of membrane encounter. Also here, arginine at position 39 is critical for PA binding, oligomerization and fungal cell killing (Järvå et al., 2018a). Additionally, $\mathrm{NaD1}$ also targets $\mathrm{PI}(4,5) \mathrm{P}_{2}$ (Figure 1), thereby seven dimers of $\mathrm{NaD} 1$ bind anionic headgroups of $14 \mathrm{PIP}_{2}$ molecules through a cationic grip configuration. Lysine at position 36 and arginine at position
40 are of importance for the NaD1 - $\mathrm{PIP}_{2}$ interaction (Poon et al., 2014; Bleackley et al., 2016). This interaction seems to be essential for NaDl's activity on tumor cells, whereas it does not seem to be essential for its antifungal activity. Nevertheless, it can be challenging to identify relevant interaction partners, since AMPs, in particular plant defensins, have multiple targets so eliminating one can weaken but does not necessarily abolish antifungal activity. Likewise, TPP3 adopts a cationic grip dimer conformation that mediates binding of $\mathrm{PIP}_{2}$ in vitro (Baxter et al., 2015). Also NsD7 interacts with $\mathrm{PI}(4,5) \mathrm{P}_{2}$. In this case the oligomeric topology formed by NsD7- $\mathrm{PIP}_{2}$ is nearly identical to the previously determined $\mathrm{NaD} 1-\mathrm{PIP}_{2}$ complex (Järvå et al., 2017). Both hBD-2 and hBD-3 are also able to interact with

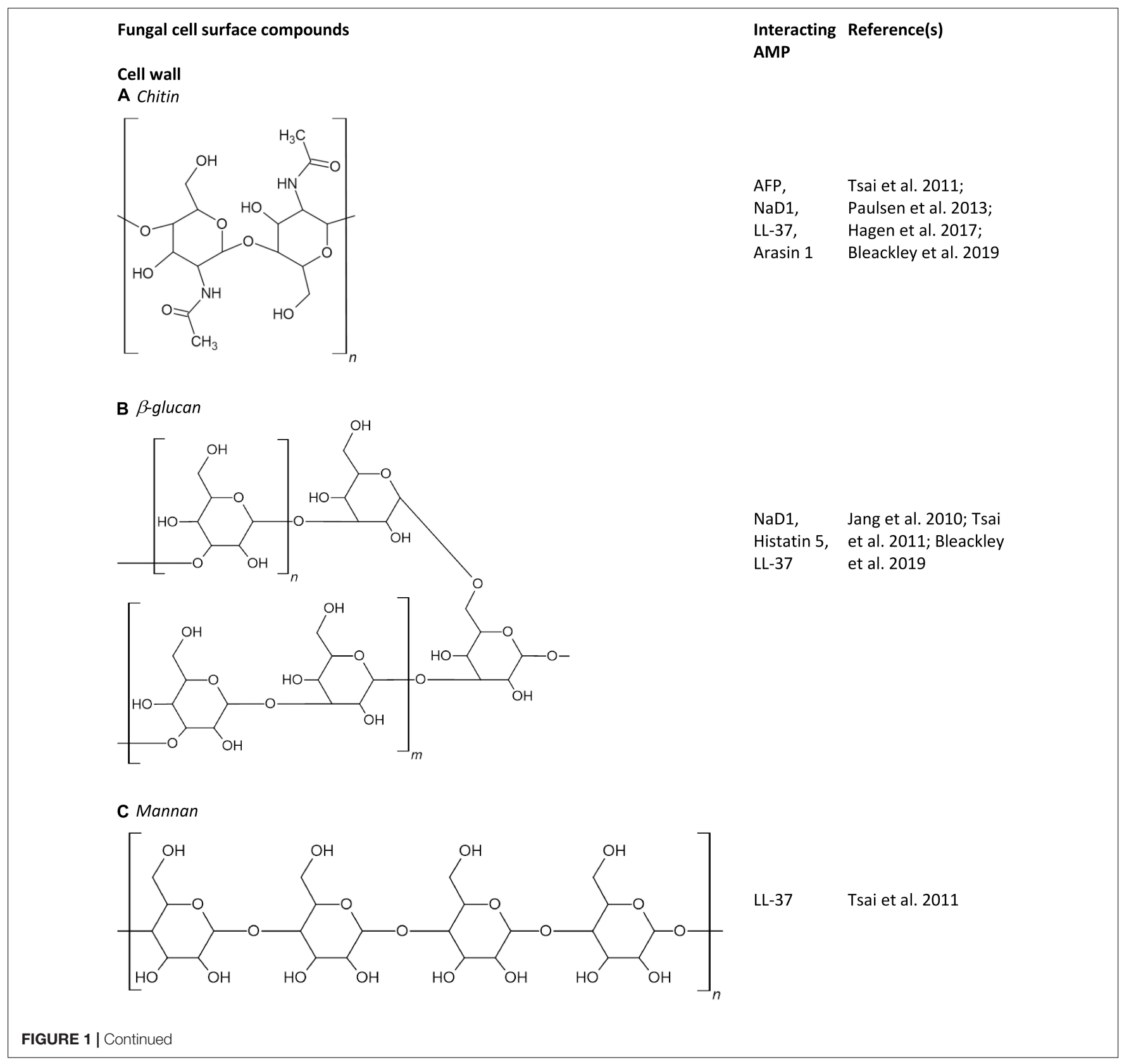




\section{Fungal cell surface compounds}

\section{Cell membrane}

A Glucosylceramide (GlcCer)<smiles>CCCCCCCC/C=C(\C)CCC/C=C/[C@@H](O)[C@@H](COC1OC(CO)C(O)C(O)C1O)NC(=O)[C@H](O)CCCCCCCCCCCCCCCC</smiles>

B Mannosyldiinositolphosphorylceramide $\left(\mathrm{M}(\mathrm{IP}){ }_{2} \mathrm{C}\right)$

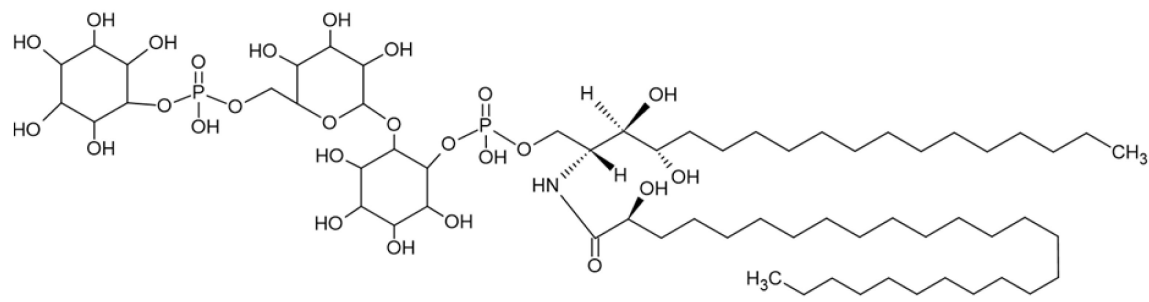

C Phosphatidic acid (PA)<smiles>CCCCCCCCCCCCCCCC(=O)OC[C@H](COP(=O)(O)O)OC(=O)CCCCCCCCCC</smiles>

D Phosphatidylinositol 4,5 bisphosphate $\left(P I(4,5) P_{2}\right)$<smiles>CCCCCC/C=C/C/C=C/C/C=C/C/C=C/CCCCCCCCC(=O)OCC(COP(=O)(O)C1C(O)C(O)C(P(=O)(O)O)C(P(=O)(O)O)C1O)OC(=O)CCCCCCCCCCCC</smiles>

E Phosphatidylinositol 3 phosphate (PI3P)<smiles>CCCCCCCCCC=CCC=CCC=CCCCCCCCCCC(=O)OCC(COP(=O)(O)C1C(O)C(O)C(O)C(P(=O)(O)O)C1O)OC(=O)CCCCCCCCCCC</smiles>

F Phosphatidylethanolamine (PE)<smiles>CCCCCCCC/C=C/CCCCCCCCCCCC(=O)OC[C@H](COP(=O)(O)OCCN)OC(=O)CCCCCCCCC</smiles>

Interacting Reference(s)

AMP

MsDef1, Thevissen et al. 2000b; Psd1, $\quad$ Thevissen et al. 2004;

Psd2, Ramamoorthy et al.

PvD1, 2007; De Medeiros et Sd5, al. 2010; De Paula et RsAFP2, al. 2008, 2011; De Heliomicin, Medeiros et al. 2014; PAF Mello et al. 2014; Muñoz et al. 2014; Amaral et al. 2019; Huber et al. 2019a

DmAMP1, Thevissen et al. 2000b; AtPDF2.3 Vriens 2015

HsAFP1, Sagaram et al. 2013;

MtDef4, Kvansakul et al. 2016;

NaD1, $\quad$ Payne et al. 2016;

NaD2, $\quad$ Cools et al. 2017b;

NsD7 Järvå et al. 2018a

NaD1, $\quad$ Baxter et al. 2015;

TPP3, $\quad$ Phan et al. 2016; Järvå hBD-2, et al. 2017; Järvå et al. hBD-3 2018b

OefDef1.1, Li et al. 2019; Ochiai et OsAFP1 al. 2020 


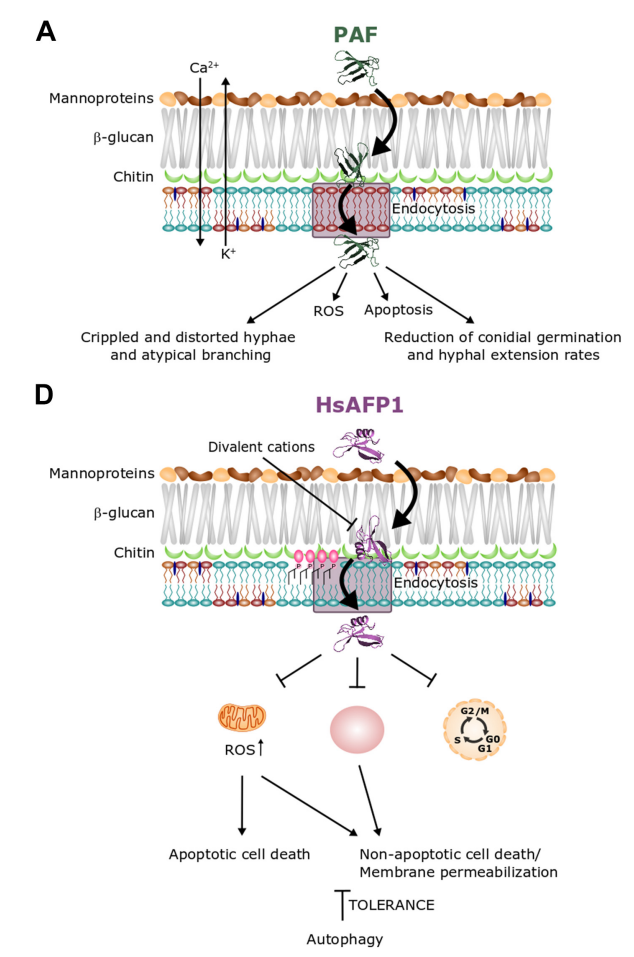

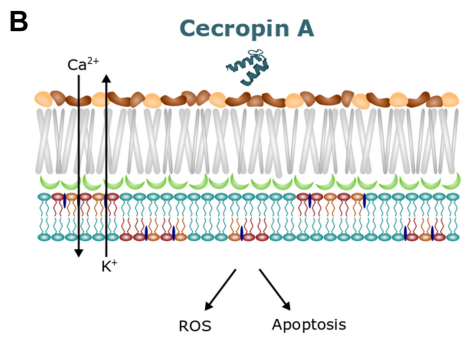

E
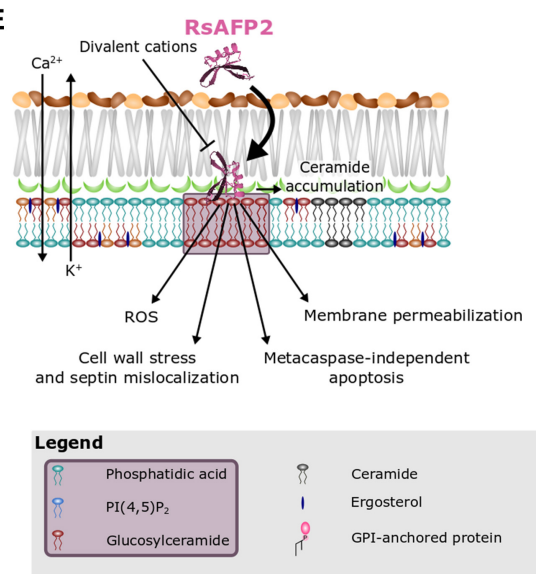

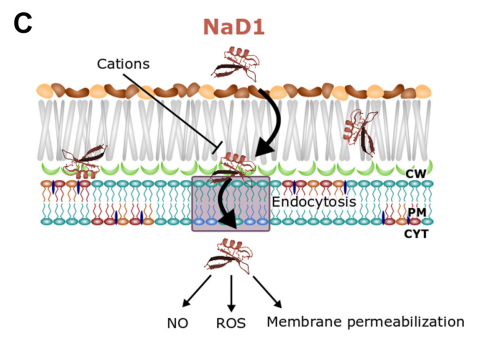

F

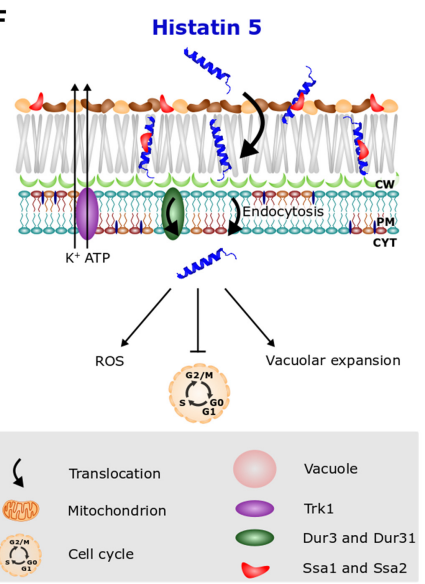

FIGURE 2 | Antifungal mode of action of (A) the Penicillium chrysogenum antifungal protein PAF and various peptides, i.e., (B) cecropin A, (C) NaD1, (D) HsAFP1, (E) RsAFP2, and (F) histatin 5. Different peptides are known to interact with different sphingo- and phospholipids, as indicated on the images and in the purple box in the legend. Note that treatment of fungal cells with rather high peptide concentrations can result in aspecific membrane permeabilization (Thevissen et al., 1997 , 1999). This phenomenon is not taken into account in this figure.

$\mathrm{PI}(4,5) \mathrm{P}_{2}$ as evaluated using lipid overlays, liposome pulldown assays and structure determination in the case of hBD-2, and using lipid overlays and lipid vesicles in case of hBD-3 (Phan et al., 2016; Järvå et al., 2018b). HBD-2 dimers specifically interact with two distinct $\mathrm{PIP}_{2}$-binding sites to permeabilize fungal cell membranes (Järvå et al., 2018b). Note that, $\mathrm{PI}(4,5) \mathrm{P}_{2}$ is localized in the inner leaflet of the cell membrane (Borges-Araújo and Fernandes, 2020), therefore, AMPs will first target other cell wall/cell membrane components. In contrast, glucose-containing glucosylceramide (GlcCer) is also found at the fungal cell wall (see section "Interaction of AMPs With the Fungal Cell Wall") (Rodrigues et al., 2000). The olive tree defensin OefDef1.1 and the rice defensin OsAFP1 are known to interact with both PI3P and PI5P, and PI3P, respectively, as validated using lipid overlays (Figure 1; Li et al., 2019; Ochiai et al., 2020). The cycloviolacin $\mathrm{O} 2$ (cyO2) is known to selectively target and disrupt membranes containing PE, as evaluated using lipid vesicles (Figure 1; Burman et al., 2011).

Apart from AMPs that interact with phospholipids, several AMPs have been identified that interact with sphingolipids. Sphingolipids, together with sterols, typically form membrane rafts, so-called lipid rafts, that are enriched in specific domains in fungal plasma membranes (Hurst and Fratti, 2020). Sphingolipids consist of a ceramide backbone linked to a polar head group. Based on this polar head group, they are classified in two groups, being phosphosphingolipids and glycosphingolipids. The phosphosphingolipid mannosyldiinositolphosphorylceramide $\left[\mathrm{M}(\mathrm{IP})_{2} \mathrm{C}\right]$ is the major sphingolipid in Saccharomyces cerevisiae (Dickson et al., 1997), and plays an important role in the antifungal mechanism of action of DmAMP1 and AtPDF2.3 (documented via an ELISA assay and/or specific yeast deletion mutants) (Figure 1; Thevissen et al., 2000a; Vriens, 2015). GlcCer is the most common glycosphingolipid in fungi, except for S. cerevisiae and Candida glabrata, since they do not produce GlcCer (Saito et al., 2006; Tavares et al., 2008). So far, GlcCer was identified to be of importance in the antifungal mode of action of numerous AMPs, such as the plant defensins MsDef1, Psd1, Psd2, PvD1, Sd5, and RsAFP2, the insect defensin-like peptide heliomicin, the Aspergillus giganteus peptide AFP and the Penicillium chrysogenum antifungal protein PAF (Figures 1, 2A,E; Thevissen et al., 2004; De Paula et al., 2008, 2011; De Medeiros et al., 2014; Mello et al., 2014; Muñoz et al., 2014; Amaral et al., 2019; Huber et al., 2019). The involvement of GlcCer in the mode of action of these AMPs was established via lipid vesicles (e.g., Psd1, Psd2, Sd5, RsAFP2, and PAF), ELISA assays (RsAFP2 and heliomicin) and deletion mutants (e.g., AFP, MsDef1, Psd1, PvD1, RsAFP2, heliomicin, and PAF) (Thevissen et al., 2000a, 2004; Ramamoorthy et al., 2007; De Paula et al., 2008, 2011; De Medeiros et al., 2010, 2014; Mello et al., 2014; Muñoz et al., 
2014; Vriens, 2015; Amaral et al., 2019; Huber et al., 2019). Often multiple biochemical tests are used to confirm the relevance of these potential interactions. Note that RsAFP2 interacts with GlcCers isolated from Pichia pastoris but not with those of soybean nor human GlcCers, whereas heliomicin interacts with GlcCers isolated from both $P$. pastoris and soybean but not with human GlcCers. Moreover, RsAFP2 and heliomicin were suggested to interact with different motifs of fungal GlcCer, as the interaction of RsAFP2 with fungal GlcCer could not be competed for by heliomicin and vice versa (Thevissen et al., 2004). Interestingly, although most sphingolipids are non-essential for cell survival, they are key regulators of pathogenicity in a variety of fungi, such as C. albicans, which makes them essential for in vivo infections (Noble et al., 2010). Therefore, the incidence of in vivo resistance development against sphingolipid-targeting AMPs is expected to be minimal as resistant mutants with defective sphingolipid biosynthesis are not virulent (Del Poeta et al., 2014).

Antimicrobial proteins can also interact with plasma membrane proteins. Human lactoferrin targets the plasma membrane Pmalp $\mathrm{H}^{+}$-ATPase, thereby perturbating cation homeostasis (cfr. supra) (Andrés et al., 2016, 2019).

\section{Interaction of AMPs With the Fungal Cell Wall}

Apart from the interaction of AMPs with the fungal cell membrane, AMPs can also interact with the fungal cell wall which is mainly composed of glucans, chitin and glycosylated proteins (Garcia-Rubio et al., 2020). Note that there are differences in cell wall composition between fungal species, e.g., galactomannan makes up a major part of the Aspergillus cell wall. Consequently, its presence is currently used as a diagnostic test for invasive aspergillosis (Mercier et al., 2018). GlcCer is also found at the fungal cell wall (Rodrigues et al., 2000), explaining the interaction of RsAFP2 with the fungal cell wall (Thevissen et al., 2012). Moreover, AMPs can also interact with other cell wall specific compounds. Recently, the interaction of both chitin and $\beta$-glucan with the tobacco plant defensin NaD1 was described (Figures 1, 2C). Herein, the yeast cell wall protects target cells against the antifungal activity of $\mathrm{NaD} 1$, as the killing of spheroplasts occurred at lower concentrations as compared to cells with intact walls (Bleackley et al., 2019). Note that AMPs can have multiple fungal targets, as $\mathrm{NaD} 1$ also interacts with $\mathrm{PA}$ and $\mathrm{PIP}_{2}$ (Figure 2C) (cfr. infra). The salivary peptide histatin 5 interacts with $\beta$-glucan, as well as with the heat shock proteins Ssa1p and Ssa2p that are present in the cell wall and cell membrane of C. albicans cells (Figures 1, 2F; Li et al., 2003; Jang et al., 2010). Binding with the latter is required for the fungicidal activity of histatin 5 (Li et al., 2003). Similarly, the human $\beta$-defensins hBD-2 and hBD-3 bind Ssalp and Ssa2p as part of their antifungal mode of action (Vylkova et al., 2006). The human neutrophil defensin 1 (HNP-1) competes with histatin 5 for Ssa1p and Ssa2p binding sites, however, using deletion mutants, it could be demonstrated that HNP-1 does not require Ssa1p or Ssa2p for its fungicidal activity (Edgerton et al., 2000; Vylkova et al., 2006). The human cathelicidin LL37 preferentially interacts with mannan, but also with chitin or glucan (Figure 1; Tsai et al., 2011). Likewise, the proline-rich antimicrobial peptide arasin 1 from spider crab also binds chitin (Figure 1). However, this chitin-binding property may also arise from its involvement in host wound healing (Paulsen et al., 2013). Also AFP binds chitin as validated in vitro (Figure 1; Hagen et al., 2007).

\section{Influence of Cations on the Initial Association of AMPs With the Fungal Cell Surface}

The initial association of cationic AMPs with anionic bilayers is mostly directed by electrostatic interactions due to their net charge being opposed to that of the target membrane (von Deuster and Knecht, 2011; Alvares et al., 2017). Therefore, the presence of cations can significantly reduce the antifungal activity of AMPs, as demonstrated in case of e.g., AFP, coprisin (dung beetle), DmAMP1, HNP-1, HsAFP1, indolicidin (cattle), NaD1, OefDef1.1, P113 (a 12-amino-acid fragment of histatin 5), RsAFP2, and hBD-1,-2 (Figures 2C-E; Osborn et al., 1995; Goldman et al., 1997; Bals et al., 1998; Edgerton et al., 2000; Lee et al., 2003, 2012, 2014; Theis et al., 2003; Bleackley et al., 2019; Li et al., 2019; Cheng et al., 2020). Similarly, in yeast mutants lacking Agp2p, a plasma membrane regulator of polyamine and carnitine transport, the antifungal activity of $\mathrm{NaD} 1$ is significantly reduced. Deletion of AGP2 was suggested to result in an accumulation of cationic molecules at the cell surface, thereby repelling cationic AMPs (Bleackley et al., 2014). Since the hydrolysis of the cell wall by zymolyase treatment restored the activity of $\mathrm{NaD1}$ in high salt conditions (100 $\mathrm{mM} \mathrm{NaCl})$, the loss of antifungal activity at elevated salt concentrations was recently attributed to the sequestration of cations by fungal cell wall polysaccharides (Bleackley et al., 2019). Note that Bleackley et al. (2019) only evaluated the effect of monovalent cations, being $\mathrm{Na}^{+}$, thereby reporting the plant defensin DmAMP1 to be salt tolerant. In contrast, Osborn et al. (1995) earlier reported that the antifungal activity of DmAMP1 against both $N$. crassa and Fusarium culmorum is significantly reduced in the presence of both 1 and $5 \mathrm{mM} \mathrm{Ca}^{2+}$ or $\mathrm{Mg}^{2+}$. Hence, it remains unclear if divalent cations are also sequestrated by fungal cell wall polysaccharides. In case of the plant defensin HsAFP1, the presence of divalent cations specifically reduced the uptake of the peptide, thereby inhibiting its antifungal activity (Figure 2D; Struyfs et al., 2020). The salt-sensitivity of most peptides (at least in vitro) is probably one of the main factors why only few AMPs have been further developed into a commercial antifungal or antibacterial product. However, there are few reports on the efficacy of AMPs upon systemic administration, thus acting in biological cation-containing fluids like blood, in preclinical models (see conclusion section of this review). For example, the plant defensin RsAFP2 demonstrated in vivo efficacy in a prophylactic murine model of candidiasis upon intravenous administration (Tavares et al., 2008). Only a limited number of AMPs are salt tolerant of which most originate from marine organisms (Lee et al., 1997; Fedders et al., 2008). Also the antifungal activity of dermcidin, expressed in sweat glands, is maintained at high salt concentrations that resemble human sweat conditions. Since dermcidin is negatively charged at physiological $\mathrm{pH}$, electrostatic interactions with membrane lipids might not be of importance for its antifungal activity 
(Schittek et al., 2001). Exceptionally, the presence of divalent cations can also enhance the antifungal activity of AMPs. Histatin 5 binds multiple cations, including $\mathrm{Zn}^{2+}$ which induces dimerization of the peptide. $\mathrm{Zn}^{2+}$ that is abundantly present in saliva, significantly increases killing activity of histatin 5 in both C. albicans and C. glabrata (Norris et al., 2020).

\section{Downstream Pathways Involved in the Antifungal Mode of Action of AMPs Potential AMP Uptake}

Previously, it was believed that the mode of action of AMPs solely consisted of simple pore formation that resulted in rapid killing. However, antifungal AMPs can have a more complex mechanism of action that includes signaling pathways and intracellular targets. Hitherto, the mechanism of action of only a limited number of AMPs has been described. Amongst them are AMPs that (i) are internalized upon their initial interaction with the fungal cell, without causing fungal membrane disruption (e.g., histatin 5, HsAFP1, MtDef4, NaD1, Neosartorya fischeri antifungal protein NFAP, OefDef1.1, Psd1 and PAF) (Figures $\mathbf{2 A}, \mathbf{D}, \mathbf{F}$ ) or (ii) remain outside the cell (e.g., RsAFP2) (Figure 2E; Oberparleiter et al., 2003; Kumar et al., 2011; Thevissen et al., 2012; El-Mounadi et al., 2016; Cools et al., 2017b; Hajdu et al., 2019; Li et al., 2019). Note that internalization is not essential for inducing intracellular mechanisms, as RsAFP2 is not internalized, but does induce e.g., production of ROS and programmed cell death (Aerts et al., 2007; Thevissen et al., 2012). The internalization process of AMPs can be species-specific. In Fusarium oxysporum and Fusarium virguliforme, the translocation of OefDef1.1 to the cytoplasm occurs in both germlings and conidia. However, in Botrytis cinerea, uptake only occurs in germlings ( $\mathrm{Li}$ et al., 2019). In N. crassa, the internalization of MtDef4 depends on the presence of phospholipase D, whereas this is not the case in Fusarium graminearum (Sagaram et al., 2011; El-Mounadi et al., 2016). The uptake of AMPs is often an active, energy requiring process, pointing to endocytosis as in case of HsAFP1, histatin 5, MtDef4, NaD1, NFAP, and PAF (Figures 2A,C,D,F; Oberparleiter et al., 2003; Jang et al., 2010; Kumar et al., 2011; Puri and Edgerton, 2014; ElMounadi et al., 2016; Cools et al., 2017b; Hayes et al., 2018; Hajdu et al., 2019). Indeed, in N. crassa, internalization of MtDef4 is energy dependent and requires endocytosis, while in F. graminearum, uptake is only partially energy dependent (El-Mounadi et al., 2016). Internalization of histatin 5 can occur via three different pathways (Figure 2F) being (i) endocytosis, (ii) transportation into the fungal cell via the polyamine transporters Dur3p and Dur31p in an energydependent process, and (iii) membrane lytic effects if the histatin concentration, estimated $15-30 \mu \mathrm{M}$ in saliva, exceeds 30 MM (Kumar et al., 2011; Puri and Edgerton, 2014). Deletion of the GPI-anchor remodeling enzyme BST1 results in increased resistance of $S$. cerevisiae cells to HsAFP1 treatment due to a compromised HsAFP1 internalization pathway, pointing to an important role for GPI-anchor remodeling enzymes in HsAFP1's internalization (Figure 2D; Struyfs et al., 2020).

\section{Production of Endogenous ROS and the Induction of Programmed Cell Death}

Similar to certain antimycotics (e.g., amphotericin B), numerous AMPs, such as the plant defensin ApDef1, cecropin A, coprisin, histatin 5, HsAFP1, human lactoferrin, the plant defensin LpDef1, NaD1, OefDef1.1, the honeybee venom peptide melittin, PAF, the Penicillium chrysogenum antifungal protein C (PAFC), PvD1, RsAFP2 and the centipede peptide scolopendin induce the production of ROS (Figure 2; Leiter et al., 2005; Andrés et al., 2008; Park and Lee, 2010; Aerts et al., 2011; Mello et al., 2011; Lee et al., 2012, 2016; Galgóczy et al., 2013; Choi et al., 2014; Yun and Lee, 2016; Soares et al., 2017; Vriens et al., 2017; Holzknecht et al., 2020). Excessive cellular levels of ROS can cause oxidative damage to proteins, nucleic acids, lipids, membranes and organelles, which in turn can lead to activation of cell death processes such as programmed cell death (Redza-Dutordoir and Averill-Bates, 2016). Programmed cell death is a tightly regulated and highly conserved process of cell death in which plasma membrane integrity is initially preserved and intracellular content is degraded in a programmed manner. Numerous AMPs are known to induce programmed cell death, such as ApDef1, cecropin A, coprisin, hBD-2, HsAFP1, human lactoferrin, melittin, NPAF, OsAFP1, PAF, RsAFP2, and scolopendin (Figures 2A,B,D,E; Leiter et al., 2005; Andrés et al., 2008; Yount et al., 2009; Park and Lee, 2010; Aerts et al., 2011; Lee et al., 2012, 2016; Thevissen et al., 2012; Galgóczy et al., 2013; Yun and Lee, 2016; Soares et al., 2017; Ochiai et al., 2018). In C. albicans, RsAFP2 treatment results in cell wall stress, septin mislocalization and increased ceramide levels, the latter having been previously demonstrated to result in programmed cell death (Thevissen et al., 2012; Rego et al., 2014). Indeed, RsAFP2 induces programmed cell death in a metacaspase-independent (Mcal) manner (Aerts et al., 2007). Nevertheless, the exact mechanism of programmed cell death induction is hitherto unclear. In contrast, ApDef1 induces chromatin condensation, resulting in cell death via metacaspasedependent programmed cell death (Soares et al., 2017). Similarly, metacaspase-dependent programmed cell death is induced upon treatment with coprisin, preceded by the exposure of PS on the outer leaflet of the plasma membrane, dysfunctional mitochondrial transmembrane potential $(\Delta \psi \mathrm{m})$ and cytochrome C release (Lee et al., 2012). Human lactoferrin induces metacaspase-dependent programmed cell death in C. albicans, as lactoferrin-treated cells exhibited PS exposure, chromatin condensation and DNA degradation (Andrés et al., 2008; AcostaZaldívar et al., 2016). Also scolopendin treatment induces programmed cell death via metacaspase activation, as evidenced by PS externalization, cytochrome $\mathrm{C}$ release, de-energization, chromatin condensation and DNA fragmentation (Lee et al., 2016). Cecropin A triggers programmed cell death characterized by PS externalization, cytochrome $C$ release, dissipation of $\Delta \psi \mathrm{m}$ and DNA fragmentation (Yun and Lee, 2016). Upon treatment with hBD-2, apoptotic cell death follows PS accessibility in 
C. albicans (Yount et al., 2009). Likewise, melittin induces programmed cell death in C. albicans, as evidenced by PS externalization, and DNA and nuclear fragmentation (Park and Lee, 2010). Note that, spinigerin induces programmed cell death in a caspase independent manner in Leishmania donovan. So far, it remains unclear if this also occurs in fungal cells (Sardar et al., 2013).

\section{Mitochondrial Dysfunction}

Moreover, AMP treatment can also result in mitochondrial dysfunction, as demonstrated for coprisin, ETD151 (analog of the antifungal insect defensin heliomicin), HsAFP1, human lactoferrin, LpDef1 and scolopendin (Figure 2D; Aerts et al., 2011; Lee et al., 2012, 2016; Puri and Edgerton, 2014; Vieira et al., 2015; Acosta-Zaldívar et al., 2016; Aumer et al., 2020). ETD151 does not interact directly with complexes I and III of the mitochondrial respiratory chain. Therefore, it was suggested that mitochondrial dysfunction results from mitochondrial membrane perturbation (Aumer et al., 2020). Co-incubation of HsAFP1 and sodium azide, which blocks the respiratory electron transport chain at complex IV, antagonized the antifungal activity of HsAFP1. This points to the indispensability of a functional respiratory chain for HsAFP1 antifungal action (Aerts et al., 2011). Likewise, treatment of C. albicans cells with sodium azide also results in a decreased susceptibility to coprisin, hBD-2, hBD-3, and histatin 5 (Helmerhorst et al., 1999; Vylkova et al., 2007; Lee et al., 2012). S. cerevisiae $r h o^{0}$ deletion mutants, lacking the mitochondrial genome, are more resistant to NaD1. Hence, mitochondrial respiratory activity is required for the antifungal activity of $\mathrm{NaD} 1$ (Hayes et al., 2013).

\section{ATP Efflux}

Another feature of the mechanism of action of AMPs is the release of ATP from target cells, as in the case of histatin 5, LL-37, hBD-2, and hBD-3 (Figure 2F; Koshlukova et al., 1999; Den Hertog et al., 2005; Vylkova et al., 2007). In C. albicans, histatin 5 causes a drastic reduction of intracellular ATP content, which results from the efflux of ATP (Koshlukova et al., 1999). Similarly, killing by both hBD-2 and hBD-3 involves ATP release. The magnitude and profile of ATP efflux are most similar between histatin 5 and hBD-2, as opposed to hBD-3 in which the maximal ATP release at 60 min peptide treatment only reached $50 \%$ of the ATP efflux level caused by histatin 5 (Vylkova et al., 2007). Notably, no gross membrane disruption occurs upon ATP efflux when tested with these AMPs, except in case of LL-37.

\section{Cell Cycle Impairment}

Antimicrobial peptides can also affect cell cycle progression, which is the case for ApDef1, histatin 5, HsAFP1 and Psd1 (Figures 2D,F; Baev et al., 2002; Lobo et al., 2007; Soares et al., 2017; Struyfs et al., 2020). Upon HsAFP1 treatment of $S$. cerevisiae cells, cell cycle impairment was observed. Nonetheless, this impairment was also present upon treatment with the inactive HsAFP1 mutant, HsAFP1[H32A][R52A] (Cools et al., 2017b), when tested at equimolar concentrations.
Hence, these findings indicate that HsAFP1-induced cell cycle impairment is not linked to its antifungal activity (Struyfs et al., 2020). Therefore, cell cycle impairment was considered as a non-specific secondary effect rather than the primary cause of HsAFP1's killing activity.

\section{Disruption of Cation Homeostasis}

Furthermore, AMPs can also abolish cation homeostasis in target cells, herein mostly intracellular levels of $\mathrm{Ca}^{2+}$ and $\mathrm{K}^{+}$ ions are disturbed. $\mathrm{Ca}^{2+}$ plays an important role in signal transduction pathways, where it acts as a second messenger e.g., in programmed cell death, and is mainly stored in the endoplasmic reticulum (ER) as well as in mitochondria (Kinjo and Schnetkamp, 2005). In contrast, $\mathrm{K}^{+}$is the major cytoplasmic cation, thereby mainly controlling the ionic strength of the cytoplasm, and its depletion is critical for progress on the apoptotic pathway (Baev et al., 2004). DmAMP1, RsAFP2, PAF, and cecropin $A$ induce both $\mathrm{K}^{+}$efflux and $\mathrm{Ca}^{2+}$ influx upon interaction with fungal target cells (Figures 2A,B,E; Thevissen et al., 1996, 1999; Kaiserer et al., 2003; Binder et al., 2010, 2015; Yun and Lee, 2016), whereas scolopendin, MsDef1 and MtDef4 induce $\mathrm{Ca}^{2+}$ influx and human lactoferrin and histatin 5 induce $\mathrm{K}^{+}$efflux (Figure 2F; Baev et al., 2004; Andrés et al., 2008; Muñoz et al., 2014; Lee et al., 2017). Interestingly, the potassium transporter Trk1 is required for the antifungal mode of action of histatin 5, as it was suggested to provide the essential pathway for ATP loss (Baev et al., 2004).

\section{Induction of Autophagy and Vacuolar Dysfunction}

Recently, AMPs were also found to induce autophagy, which is a cytoprotective process in which intracellular material is digested in the vacuole (Carmona-Gutierrez et al., 2018). Notably, excessive levels of autophagy have been linked with cell death (Liu and Levine, 2015). Moderate HsAFP1 doses induce autophagy in $S$. cerevisiae cells, probably as a fungal tolerance/pro-survival mechanism against the HsAFP1 action (Figure 2D; Struyfs et al., 2020). Since functional vacuoles are indispensable for the induction of autophagy (Martínez-Muñoz and Kane, 2008; Sampaio-Marques et al., 2019), they might play a role in governing tolerance to HsAFP1. Indeed, at high HsAFP1 doses vacuoles are affected, as demonstrated by the increased vacuolar $\mathrm{pH}$, possibly resulting in impaired autophagy, and therefore in effective killing of S. cerevisiae cells. After NbD6 treatment the vacuoles of both $S$. cerevisiae and F. graminearum cells fused into one large vacuole, while the peptide remained on the cell surface. Though such large vacuole resembles those that form in an autophagic response, a possible link between both must be validated (Parisi et al., 2019a). In contrast, after SBI6 treatment, cells contained multiple fragmented vacuoles, pointing to vacuolar disruption (Parisi et al., 2019a). While functional vacuoles reportedly seem to govern tolerance to HsAFP1, deletions in vacuolar genes result in increased resistance to NbD6 and SBI6 (Aerts et al., 2011; Parisi et al., 2019a). These findings indicate that these peptides do not impair vacuolar function, but that their antifungal effect rather depends on a properly functioning vacuole (Parisi et al., 2019a). 


\section{Potential Link Between the Antifungal Mode of Action of AMPs and MCSs}

In eukaryotic cells, incompatible biochemical processes are spatially separated by intracellular compartmentalization in organelles. Most organelles are physically connected via MCSs (Kohler et al., 2020). Notably, at MCSs, organelle membranes are closely apposed and tethered, however, not fused (Scorrano et al., 2019). MCSs play a critical role in inter-organelle communication that is essential in maintaining cellular homeostasis, including lipid synthesis and trafficking, and intracellular signaling (e.g., $\mathrm{Ca}^{2+}$ ) (Scorrano et al., 2019). Although there is currently no evidence of MCS involvement in the mode of action of AMPs, it could be linked with their antifungal activity. In particular, MCSs play an important role in the regulation of autophagy, as the MCSs between the phagophore and the ER allow the direct transfer of lipids that are required for membrane extension, and thus the progression of autophagy (Molino et al., 2017; Kohler et al., 2020). Moreover, the endosomal protein Vps13p transiently localizes to nucleus-vacuole junctions in yeast (Lang et al., 2015). Interestingly, the S. cerevisiae $\Delta v p s 13$ deletion mutant is 4fold more resistant to HsAFP1 (Aerts et al., 2011), pointing to a potential link between MCSs and HsAFP1 functioning. Furthermore, MCSs are involved in $\mathrm{Ca}^{2+}$ homeostasis at the ER-mitochondria interface (Phillips and Voeltz, 2016), and disruption of cation homeostasis is part of the antifungal activity of numerous AMPs. Hence, MCSs could be involved in the antifungal mode of action of AMPs. This hypothetical link should be further investigated by different techniques, such as superresolution microscopy, transmission electron microscopy, FRETbased reporters or proximity ligation assays, in the presence and absence of AMPs to evaluate their potential effect on MCSs (Nascimbeni et al., 2017; Scorrano et al., 2019).

\section{CONCLUSION}

Antimicrobial peptides are part of the innate immune system of numerous organisms and are known for their broad-spectrum activity. Their structure is highly diverse and grouped according to their conserved 3D structure. In the past, the mode of action of AMPs was generally considered as nonspecific, resulting in rapid physical disruption of microbial cell membranes causing cell leakage and death. However, AMPs can also exert a more complex mechanism of action. Many AMPs specifically interact with the fungal cell wall and/or cell membrane, with various sphingolipids and phospholipids identified as AMP targets. Upon target interaction, peptides can be internalized or can remain at the outside of the fungal cell. Regardless of potential uptake, antifungal peptides can affect intracellular targets, thereby resulting in a multitude of actions such as ROS production, programmed cell death, mitochondrial dysfunction, disruption of cation homeostasis, ATP efflux, cell cycle impairment, autophagy, and vacuolar dysfunction. Moreover, MCSs might be linked with the mode of action of antifungal AMPs.

Elucidating the mode of action of AMPs is a crucial step to exploit their application potential. Hitherto, the activity of certain
AMPs is demonstrated in vivo as exemplified by RsAFP2's activity in a prophylactic murine model of candidiasis and by the histatin 5 derivative P113's activity against oral candidiasis that completed clinical phase IIb (Tavares et al., 2008; Brunetti et al., 2016; Håkansson et al., 2019; Mookherjee et al., 2020). Inactivation of AMPs by cations upon systemic administration could be limiting for commercial applications, however, alternative administration routes, such as topical administration, in which the inactivation of AMPs by cations is of less importance, could be of interest. For example, ropocamptide, developed by ProMore Pharma, Sweden, is based on LL-37 [known to be inactivated by $100 \mathrm{mM}$ $\mathrm{NaCl}$ (Turner et al., 1998)] and has recently passed clinical phase IIb study in patients with venous leg ulcers to improve chronic would healing (Thapa et al., 2020; Promore Pharma, 2021). As compared to small molecules, peptides mostly have a greater efficacy, selectivity and specificity (Hummel et al., 2006; McGregor, 2008, Henninot et al., 2018). Nonetheless, they are also more prone to degradation as compared to small moleculebased drugs. To overcome this limitation, non-natural amino acids and/or cyclization can be introduced to enhance peptide stability (Ding et al., 2020). Numerous AMP-based drugs are currently evaluated in clinical trials [as reviewed in Mookherjee et al. (2020)] for a variety of potential applications, such as antimicrobial therapies and immunomodulatory therapies. Apart from directly exploiting antifungal peptides and their derivatives, insight in the mechanism of action of AMPs can also be used to facilitate the efficient design and development of novel AMP-like antifungal compounds with high selectivity. This can be exemplified by fungal GlcCer-specific camelid single domain antibodies, which were designed to mimic RsAFP2's interaction with GlcCer and hence, are active against a broad spectrum of plant pathogenic fungi (De Coninck et al., 2017). This points to the potential of AMPs in a myriad of novel applications.

\section{AUTHOR CONTRIBUTIONS}

KT coordinated the review of the manuscript. BC revised the review of the manuscript. CS contributed to writing of the manuscript, redaction, and revisions. All authors contributed to the article and approved the submitted version.

\section{FUNDING}

This work was received funding from Research Foundation Flanders (FWO) (SB fellowship 1S38618N, Research projects G080016N and G0C6418N). KT acknowledges receipt of a mandate of IOF, KU Leuven (IOFm/05/022).

\section{SUPPLEMENTARY MATERIAL}

The Supplementary Material for this article can be found online at: https://www.frontiersin.org/articles/10.3389/fcell.2021. 649875/full\#supplementary-material 


\section{REFERENCES}

Acosta-Zaldívar, M., Andrés, M. T., Rego, A., Pereira, C. S., Fierro, J. F., and CôrteReal, M. (2016). Human lactoferrin triggers a mitochondrial- and caspasedependent regulated cell death in Saccharomyces cerevisiae. Apoptosis 21, 163-173. doi: 10.1007/s10495-015-1199-9

Aerts, A. M., Bammens, L., Govaert, G., Carmona-Gutierrez, D., Madeo, F., Cammue, B. P. A., et al. (2011). The antifungal plant defensin HsAFP1 from Heuchera sanguinea induces apoptosis in Candida albicans. Front. Microbiol. 2:47. doi: 10.3389/fmicb.2011.00047

Aerts, A. M., François, I. E. J. A., Bammens, L., Cammue, B. P. A., Smets, B., Winderickx, J., et al. (2006). Level of $\mathrm{M}(\mathrm{IP})_{2} \mathrm{C}$ sphingolipid affects plant defensin sensitivity, oxidative stress resistance and chronological life-span in yeast. FEBS Lett. 580, 1903-1907. doi: 10.1016/j.febslet.2006.02.061

Aerts, A. M., François, I. E. J. A., Meert, E. M. K., Li, Q. T., Cammue, B. P. A., and Thevissen, K. (2007). The antifungal activity of RsAFP2, a plant defensin from Raphanus sativus, involves the induction of reactive oxygen species in Candida albicans. J. Mol. Microbiol. Biotechnol. 13, 243-247. doi: 10.1159/000104753

Allen, A., Snyder, A. K., Preuss, M., Nielsen, E. E., Shah, D. M., and Smith, T. J. (2008). Plant defensins and virally encoded fungal toxin KP4 inhibit plant root growth. Planta 227, 331-339. doi: 10.1007/s00425-007-0620-1

Almeida, M. S., Cabral, K. M. S., Kurtenbach, E., Almeida, F. C. L., and Valente, A. P. (2002). Solution structure of Pisum sativum defensin 1 by high resolution NMR: plant defensins, identical backbone with different mechanisms of action. J. Mol. Biol. 315, 749-757. doi: 10.1006/jmbi.2001.5252

Almeida, M. S., Cabral, K. M. S., Zingali, R. B., and Kurtenbach, E. (2000). Characterization of two novel defense peptides from pea (Pisum sativum) seeds. Arch. Biochem. Biophys. 378, 278-286. doi: 10.1006/abbi.2000.1824

Almeida, P. F., and Pokorny, A. (2012). Interactions of antimicrobial peptides with lipid bilayers. Biophys. J. 5, 189-222. doi: 10.1016/B978-0-12-374920-8.00515-4

Alvares, D. S., Viegas, T. G., and Neto, J. R. (2017). Lipid-packing perturbation of model membranes by $\mathrm{pH}$-responsive antimicrobial peptides. Biophys. Rev. 9, 669-682. doi: 10.1007/s12551-017-0296-0

Amaral, V. S. G., Fernandes, C. M., Felício, M. R., Valle, A. S., Quintana, P. G., Almeida, C. C., et al. (2019). Psd2 pea defensin shows a preference for mimetic membrane rafts enriched with glucosylceramide and ergosterol. Biochim. Biophys. Acta Biomembr. 1861, 713-728. doi: 10.1016/j.bbamem.2018. 12.020

Andrä, J., Berninghausen, O., and Leippe, M. (2001). Cecropins, antibacterial peptides from insects and mammals, are potently fungicidal against Candida albicans. Med. Microbiol. Immunol. 189, 169-173. doi: 10.1007/s430-001-8 025-x

Andrés, M. T., Acosta-Zaldívar, M., and Fierro, J. F. (2016). Antifungal mechanism of action of lactoferrin: identification of $\mathrm{H}^{+}$-ATPase (P3A-type) as a new apoptotic-cell membrane receptor. Antimicrob. Agents Chemother. 60, 42064216. doi: 10.1128/AAC.03130-15

Andrés, M. T., Acosta-Zaldívar, M., González-Seisdedos, J., and Fierro, J. F. (2019). Cytosolic acidification is the first transduction signal of lactoferrin-induced regulated cell death pathway. Int. J. Mol. Sci. 20, 5838-5854. doi: 10.3390/ ijms20235838

Andrés, M. T., Viejo-Díaz, M., and Fierro, J. F. (2008). Human lactoferrin induces apoptosis-like cell death in Candida albicans: critical role of $\mathrm{K}^{+}$-channelmediated $\mathrm{K}^{+}$efflux. Antimicrob. Agents Chemother. 52, 4081-4088. doi: 10. 1128/AAC.01597-07

Aumer, T., Voisin, B. N., Knobloch, T., Landon, C., and Bulet, P. (2020). Impact of an antifungal insect defensin on the proteome of the phytopathogenic fungus Botrytis cinerea. J. Proteome. Res. 19, 1131-1146. doi: 10.1021/acs.jproteome. $9 \mathrm{~b} 00638$

Baev, D., Li, X. S., Dong, J., Keng, P., and Edgerton, M. (2002). Human salivary histatin 5 causes disordered volume regulation and cell cycle arrest in Candida albicans. Infect. Immun. 70, 4777-4784. doi: 10.1128/IAI.70.9.4777-4784.2002

Baev, D., Rivetta, A., Vylkova, S., Sun, J. N., Zeng, G. F., Slayman, C. L., et al. (2004). The TRK1 potassium transporter is the critical effector for killing of Candida albicans by the cationic protein, histatin 5. J. Biol. Chem. 279, 55060-55072. doi: 10.1074/jbc.M411031200

Bals, R., Wang, X., Wu, Z., Freeman, T., Bafna, V., Zasloff, M., et al. (1998). Human $\beta$-defensin 2 is a salt-sensitive peptide antibiotic expressed in human lung. J. Clin. Investig. 102, 874-880. doi: 10.1172/JCI2410
Baxter, A. A., Richter, V., Lay, F. T., Poon, I. K. H., Adda, C. G., Veneer, P. K., et al. (2015). The tomato defensin TPP3 binds phosphatidylinositol $(4,5)$ bisphosphate via a conserved dimeric cationic grip conformation to mediate cell lysis. Mol. Cell. Biol. 35, 1964-1978. doi: 10.1128/mcb.00282-15

Benedict, K., Jackson, B. R., Chiller, T., and Beer, K. D. (2019). Estimation of direct healthcare costs of fungal diseases in the United States. Clin. Infect. Dis. 68, 1791-1797. doi: 10.1093/cid/ciy776

Benincasa, M., Scocchi, M., Pacor, S., Tossi, A., Nobili, D., Basaglia, G., et al. (2006). Fungicidal activity of five cathelicidin peptides against clinically isolated yeasts. J. Antimicr. Chemother. 58, 950-959. doi: 10.1093/jac/dkl382

Binder, U., Benèina, M., Fizil, A., Batta, G., Chhillar, A. K., and Marx, F. (2015). Protein kinase A signaling and calcium ions are major players in PAF mediated toxicity against Aspergillus niger. FEBS Lett. 589, 1266-1271. doi: 10.1016/j. febslet.2015.03.037

Binder, U., Chu, M., Read, N. D., and Marx, F. (2010). The antifungal activity of the Penicillium chrysogenum protein PAF disrupts calcium homeostasis in Neurospora crassa. Eukaryot. Cell 9, 1374-1382. doi: 10.1128/EC.00050-10

Bleackley, M. R., Dawson, C. S., McKenna, J. A., Quimbar, P., Hayes, B. M. E., van der Weerden, N. L., et al. (2017). Synergistic activity between two antifungal proteins, the plant defensin $\mathrm{NaD} 1$ and the bovine pancreatic trypsin inhibitor. mSphere 2:e00390-17. doi: 10.1128/mSphere.00390-17

Bleackley, M. R., Dawson, C. S., Payne, J. A. E., Harvey, P. J., Rosengren, K. J., Quimbar, P., et al. (2019). The interaction with fungal cell wall polysaccharides determines the salt tolerance of antifungal plant defensins. Cell Surface 5:100026. doi: 10.1016/j.tcsw.2019.100026

Bleackley, M. R., Payne, J. A. E., Hayes, B. M. E., Durek, T., Craik, D. J., Shafee, T. M. A., et al. (2016). Nicotiana alata defensin chimeras reveal differences in the mechanism of fungal and tumor cell killing and an enhanced antifungal variant. Antimicrob. Agents Chemother. 60, 6302-6312. doi: 10.1128/AAC.01479-16

Bleackley, M. R., Wiltshire, J. L., Perrine-Walker, F., Vasa, S., Burns, R. L., van der Weerden, N. L., et al. (2014). Agp2p, the plasma membrane transregulator of polyamine uptake, regulates the antifungal activities of the plant defensin NaD1 and other cationic peptides. Antimicrob. Agents Chemother. 58, 2688-2698. doi: 10.1128/AAC.02087-13

Bongomin, F., Gago, S., Oladele, R. O., and Denning, D. W. (2017). Global and multi-national prevalence of fungal diseases-estimate precision. J. Fungi 3, 1-29. doi: 10.3390/jof3040057

Boniotto, M., Jordan, W. J., Eskdale, J., Tossi, A., Antcheva, N., Crovella, S., et al. (2006). Human $\beta$-defensin 2 induces a vigorous cytokine response in peripheral blood mononuclear cells. Antimicrob. Agents Chemother. 50, 1433-1441. doi: 10.1128/AAC.50.4.1433-1441.2006

Borges-Araújo, L., and Fernandes, F. (2020). Structure and lateral organization of phosphatidylinositol 4,5-bisphosphate. Molecules 25:3885. doi: 10.3390/ molecules25173885

Broekaert, W. F., Cammue, B. P. A., De Bolle, M. F. C., Thevissen, K., De Samblanx, G. W., Osborn, R. W., et al. (1997). Antimicrobial peptides from plants. Crit. Rev. Plant Sci. 16, 297-323. doi: 10.1080/07352689709701952

Brogden, K. A. (2005). Antimicrobial peptides: pore formers or metabolic inhibitors in bacteria? Nat. Rev. Microbiol. 3, 238-250. doi: 10.1038/ nrmicro1098

Brown, G. D., Denning, D. W., Gow, N. A. R., Levitz, S. M., Netea, M. G., and White, T. C. (2012). Hidden killers: human fungal infections. Sci. Transl. Med. 4:165rv13. doi: 10.1126/scitranslmed.3004404

Brunetti, J., Falciani, C., Roscia, G., Pollini, S., Bindi, S., Scali, S., et al. (2016). In vitro and in vivo efficacy, toxicity, bio-distribution and resistance selection of a novel antibacterial drug candidate. Sci. Rep. 6:26077. doi: 10.1038/srep26077

Buda De Cesare, G., Cristy, S. A., Garsin, D. A., and Lorenz, M. C. (2020). Antimicrobial peptides: a new frontier in antifungal therapy. mBio 11:e2123-20. doi: $10.1128 / \mathrm{mBio} .02123-20$

Burman, R., Strömstedt, A. A., Malmsten, M., and Göransson, U. (2011). Cyclotidemembrane interactions: defining factors of membrane binding, depletion and disruption. Biochim. Biophys. Acta 1808, 2665-2673. doi: 10.1016/j.bbamem. 2011.07.004

Carmona-Gutierrez, D., Bauer, M. A., Zimmermann, A., Aguilera, A., Austriaco, N., Ayscough, K., et al. (2018). Guidelines and recommendations on yeast cell death nomenclature. Microb. Cell 5, 4-31. doi: 10.15698/mic2018.01.607

Centers for Disease Control and Prevention [CDC] (2019). U.S. Department of Health and Human Services. Drug-Resistant Candida auris. Available online 
at: https://www.cdc.gov/drugresistance/pdf/threats-report/candida-auris-508. pdf (accessed on February 2021)

Cheng, K. T., Wu, C. L., Yip, B. S., Chih, Y. H., Peng, K. L., Hsu, S. Y., et al. (2020). The interactions between the antimicrobial peptide P-113 and living Candida albicans cells shed light on mechanisms of antifungal activity and resistance. Int. J. Mol. Sci. 21:2654. doi: 10.3390/ijms21072654

Cho, Y., Turner, J. S., Dinh, N. N., and Lehrer, R. I. (1998). Activity of protegrins against yeast-phase Candida albicans. Infect. Immun. 66, 2486-2493. doi: 10. 1128/IAI.66.6.2486-2493.1998

Choi, H., Hwang, J. S., and Lee, D. G. (2014). Identification of a novel antimicrobial peptide, scolopendin 1, derived from centipede Scolopendra subspinipes mutilans and its antifungal mechanism. Insect Mol. Biol. 23, 788799. doi: 10.1111/imb.12124

Cohen, L., Moran, Y., Sharon, A., Segal, D., Gordon, D., and Gurevitz, M. (2009). Drosomycin, an innate immunity peptide of Drosophila melanogaster, interacts with the fly voltage-gated sodium channel. J. Biol. Chem. 284, 23558-23563. doi: 10.1074/jbc.M109.023358

Contreras, G., Shirdel, I., Braun, M. S., and Wink, M. (2019). Defensins: transcriptional regulation and function beyond antimicrobial activity. Dev. Comp. Immunol. 104, 103556. doi: 10.1016/j.dci.2019.103556

Cools, T. L., Struyfs, C., Cammue, B. P. A., and Thevissen, K. (2017a). Antifungal plant defensins: increased insight in their mode of action as a basis for their use to combat fungal infections. Future Microbiol. 12, 441-454. doi: 10.2217/fmb2016-0181

Cools, T. L., Struyfs, C., Drijfhout, J. W., Kucharíková, S., Lobo Romero, C., Van Dijck, P., et al. (2017b). A linear 19-mer plant defensin-derived peptide acts synergistically with caspofungin against Candida albicans biofilms. Front. Microbiol. 8:2051. doi: 10.3389/fmicb.2017.02051

Cools, T. L., Vriens, K., Struyfs, C., Verbandt, S., Ramada, M. H. S., Brand, G. D., et al. (2017c). The antifungal plant defensin HsAFP1 Is a phosphatidic acidinteracting peptide inducing membrane permeabilization. Front. Microbiol. 8:2295. doi: $10.3389 /$ fmicb. 2017.02295

Czajlik, A., Holzknecht, J., Galgóczy, L., Tóth, L., Poór, P., Ördög, A., et al. (2021). Solution structure, dynamics, and new antifungal aspects of the cysteine-rich miniprotein PAFC. Int. J. Mol. Sci. 22:1183. doi: 10.3390/ijms2203 1183

Daly, N. L., Rosengren, J. K., and Craik, D. J. (2009). Discovery, structure and biological activities of cyclotides. Adv. Drug Deliv. Rev. 61, 918-930. doi: 10. 1016/j.addr.2009.05.003

De Coninck, B., Verheesen, P., Vos, C. M., Van Daele, I., De Bolle, M. F., Vieira, J. V., et al. (2017). Fungal glucosylceramide-specific camelid single domain antibodies are characterized by broad spectrum antifungal activity. Front. Microbiol. 8:1059. doi: 10.3389/fmicb.2017.01059

De Medeiros, L. N., Angeli, R., Sarzedas, C. G., Barreto-Bergter, E., Valente, A. P., Kurtenbach, E., et al. (2010). Backbone dynamics of the antifungal Psd1 pea defensin and its correlation with membrane interaction by NMR spectroscopy. Biochim. Biophys. Acta Biomembr. 1798, 105-113. doi: 10.1016/j.bbamem.2009. 07.013

De Medeiros, L. N., Domitrovic, T., De Andrade, P. C., Faria, J., Bergter, E. B., Weissmuller, G., et al. (2014). Psd1 binding affinity toward fungal membrane components as assessed by SPR: the role of glucosylceramide in fungal recognition and entry. Biopolymers 102, 456-464. doi: 10.1002/bip.22570

De Paula, V. S., Razzera, G., Barreto-Bergter, E., Almeida, F. C. L., and Valente, A. P. (2011). Portrayal of complex dynamic properties of sugarcane defensin 5 by NMR: multiple motions associated with membrane interaction. Structure 19, 26-36. doi: 10.1016/j.str.2010.11.011

De Paula, V. S., Razzera, G., Medeiros, L., Miyamoto, C. A., Almeida, M. S., Kurtenbach, E., et al. (2008). Evolutionary relationship between defensins in the Poaceae family strengthened by the characterization of new sugarcane defensins. Plant Mol. Biol. 68, 321-335. doi: 10.1007/s11103-008-9372-y

Del Poeta, M., Nimrichter, L., Rodrigues, M. L., and Luberto, C. (2014). Synthesis and biological properties of fungal glucosylceramide. PLoS Pathog. 10:e1003832. doi: 10.1371/journal.ppat.1003832

Den Hertog, A. L., Van Marle, J., Van Veen, H. A., Van't Hof, W., Bolscher, J. G. M., Veerman, E. C. I., et al. (2005). Candidacidal effects of two antimicrobial peptides: histatin 5 causes small membrane defects, but LL-37 causes massive disruption of the cell membrane. Biochem. J. 388, 689-695. doi: 10.1042/ BJ20042099
Dickson, R. C., Nagiec, E. E., Wells, G. B., Nagiec, M. M., and Lester, R. L. (1997). Synthesis of mannose-(inositol-P) $)_{2}$-ceramide, the major sphingolipid in Saccharomyces cerevisiae, requires the IPT1 (YDR072c) gene. J. Biol. Chem. 272, 29620-29625. doi: 10.1074/jbc.272.47.29620

Ding, Y., Ting, J. P., Liu, J., Al-Azzam, S., Pandya, P., and Afshar, S. (2020). Impact of non-proteinogenic amino acids in the discovery and development of peptide therapeutics. Amino Acids 52, 1207-1226. doi: 10.1007/s00726-020-02890-9

Do, N., Weindl, G., Grohmann, L., Salwiczek, M., Koksch, B., Korting, H. C., et al. (2014). Cationic membrane-active peptides - anticancer and antifungal activity as well as penetration into human skin. Exp. Dermatol. 23, 326-331. doi: 10.1111/exd.12384

do Nascimento, V. V., Mello, ÉO., Carvalho, L. P., De Melo, E. J. T., Carvalho, A. O., Fernandes, K. V. S., et al. (2015). PvD1 defensin, a plant antimicrobial peptide with inhibitory activity against Leishmania amazonensis. Biosci. Rep. 35:e0248. doi: 10.1042/BSR20150060

Dong, J., Vylkova, S., Li, X. S., and Edgerton, M. (2003). Calcium blocks fungicidal activity of human salivary histatin 5 through disruption of binding with Candida albicans. J. Dent. Res. 82, 748-752. doi: 10.1177/154405910308 200917

Dracatos, P. M., Payne, J., Di Pietro, A., Anderson, M. A., and Plummer, K. M. (2016). Plant defensins $\mathrm{NaD} 1$ and $\mathrm{NaD} 2$ induce different stress response pathways in fungi. Int. J. Mol. Sci. 17:1473. doi: 10.3390/ijms17091473

Dubos, R. J. (1939). Studies on a bactericidal agent extracted from a soil Bacillus. J. Exp. Med. 70, 11-17. doi: 10.1084/jem.70.1.1

Edgerton, M., Koshlukova, S. E., Araujo, M. W., Patel, R. C., Dong, J., and Bruenn, J. A. (2000). Salivary histatin 5 and human neutrophil defensin 1 kill Candida albicans via shared pathways. Antimicrob. Agents Chemother. 44, 3310-3306. doi: 10.1128/aac.44.12.3310-3316.2000

El-Mounadi, K., Islam, K. T., Hernández-Ortiz, P., Read, N. D., and Shah, D. M. (2016). Antifungal mechanisms of a plant defensin MtDef4 are not conserved between the ascomycete fungi Neurospora crassa and Fusarium graminearum. Mol. Microbiol. 100, 542-559. doi: 10.1111/mmi.13333

Faruck, M. O., Yusof, F., and Chowdhury, S. (2016). An overview of antifungal peptides derived from insect. Peptides 80, 80-88. doi: 10.1016/j.peptides.2015. 06.001

Fedders, H., Michalek, M., Grötzinger, J., and Leippe, M. (2008). An exceptional salt-tolerant antimicrobial peptide derived from a novel gene family of haemocytes of the marine invertebrate Ciona intestinalis. Biochem. J. 416, 65-75. doi: 10.1042/BJ20080398

Fehlbaum, P., Bulet, P., Michaut, L., Lagueux, M., Broekaert, W. F., Hetru, C., et al. (1994). Insect immunity: septic injury of Drosophila induces the synthesis of a potent antifungal peptide with sequence homology to plant antifungal peptides. J. Biol. Chem. 269, 33159-33163. doi: 10.1016/S0021-9258(20)30111-3

Feng, Z., Jiang, B., Chandra, J., Ghannoum, M., Nelson, S., and Weinberg, A. (2005). Human beta-defensins: differential activity against Candidal species and regulation by Candida albicans. J. Dent. Res. 84, 445-450. doi: 10.1177/ 154405910508400509

Ferket, K. K. A., Levery, S. B., Park, C., Cammue, B. P. A., and Thevissen, K. (2003). Isolation and characterization of Neurospora crassa mutants resistant to antifungal plant defensins. Fungal Genet. Biol. 40, 176-185. doi: 10.1016/S10871845(03)00085-9

Fisher, M., Henk, D., Briggs, C., Brownstein, J. S., Madoff, L. C., McCraw, S. L., et al. (2012). Emerging fungal threats to animal, plant and ecosystem health. Nature 484, 186-194. doi: 10.1038/nature10947

Fisher, M. C., Gurr, S. J., Cuomo, C. A., Blehert, D. S., Jin, H., Stukenbrock, E. H., et al. (2020). Threats posed by the fungal kingdom to humans, wildlife, and agriculture. mBio 11:e00449-20. doi: 10.1128/mBio.00449-20

Fisher, M. C., Hawkins, N. J., Sanglard, D., and Gurr, S. J. (2018). Worldwide emergence of resistance to antifungal drugs challenges human health and food security. Science 360, 739-742. doi: 10.1126/science.aap7999

Gácser, A., Tiszlavicz, Z., Németh, T., Seprényi, G., and Mándi, Y. (2014). Induction of human defensins by intestinal Caco- 2 cells after interactions with opportunistic Candida species. Microbes Infect. 16, 80-85. doi: 10.1016/j.micinf. 2013.09.003

Galgóczy, L., Kovács, L., Karácsony, Z., Virágh, M., Hamari, Z., and Vágvölgyi, C. (2013). Investigation of the antimicrobial effect of Neosartorya fischeri antifungal protein (NFAP) after heterologous expression in Aspergillus nidulans. Microbiolgy 159, 411-419. doi: 10.1099/mic.0.061119-0 
Gallo, R. L., Kim, K. J., Bernfield, M., Kozak, C. A., Zanetti, M., Merluzzi, L., et al. (1997). Identification of CRAMP, a cathelin-related antimicrobial peptide expressed in the embryonic and adult mouse. J. Biol. Chem. 272, 13088-13093. doi: 10.1074/jbc.272.20.13088

Gank, K. D., Yeaman, M. R., Kojima, S., Yount, N. Y., Park, H., Edwards, J. E., et al. (2008). SSD1 is integral to host defense peptide resistance in Candida albicans. Eukaryot. Cell 7, 1318-1327. doi: 10.1128/EC.00402-07

Ganz, T., Selsted, M. E., Szklarek, D., Harwig, S. S., Daher, K., Bainton, D. F., et al. (1985). Defensins. Natural peptide antibiotics of human neutrophils. J. Clin. Investig. 76, 1427-1435. doi: 10.1172/JCI112120

Gao, B., and Zhu, S. Y. (2008). Differential potency of drosomycin to Neurospora crassa and its mutant: implications for evolutionary relationship between defensins from insects and plants. Insect Mol. Biol. 17, 405-411. doi: 10.1111/ j.1365-2583.2008.00810.x

García, J. R. C., Krause, A., Schulz, S., Rodríguez-Jiménez, F. J., Klüver, E., Adermann, K., et al. (2001). Human $\beta$-defensin 4: a novel inducible peptide with a specific salt-sensitive spectrum of antimicrobial activity. FASEB J. 15, 1819-1821. doi: 10.1096/fj.00-0865fje

Garcia-Rubio, R., de Oliveira, H. C., Rivera, J., and Trevijano-Contador, N. (2020). The fungal cell wall: Candida, Cryptococcus, and Aspergillus species. Front. Microbiol. 10:2993. doi: 10.3389/fmicb.2019.02993

Gauthier, G. M., and Keller, N. P. (2013). Crossover fungal pathogens: the biology and pathogenesis of fungi capable of crossing kingdoms to infect plants and humans. Fungal Genet. Biol. 61, 146-157. doi: 10.1016/j.fgb.2013.08.016

Goldman, M. J., Anderson, M. G., Stolzenberg, E. D., Kari, P. U., Zasloff, M., and Wilson, J. M. (1997). Human $\beta$-defensin- 1 is a salt-sensitive antibiotic in lung that is inactivated in cystic fibrosis. Cell 88, 553-560. doi: 10.1016/S00928674(00)81895-4

Gomes, B., Augusto, M. T., Felício, M. R., Hollmann, A., Franco, O. L., Gonçalves, S., et al. (2018). Designing improved active peptides for therapeutic approaches against infectious diseases. Biotechnol. Adv. 36, 415-429. doi: 10. 1016/j.biotechadv.2018.01.004

Gonçalves, S., Silva, P. M., Felício, M. R., de Medeiros, L. N., Kurtenbach, E., and Santos, N. C. (2017). Psd1 effects on Candida albicans planktonic cells and biofilms. Front. Cell. Infect. Microbiol. 7:249. doi: 10.3389/fcimb.2017.00249

Hagen, S., Marx, F., Ram, A. F., and Meyer, V. (2007). The antifungal protein AFP from Aspergillus giganteus inhibits chitin synthesis in sensitive fungi. Appl. Environ. Microbiol. 73, 2128-2134. doi: 10.1128/AEM.02497-06

Hajdu, D., Huber, A., Czajlik, A., Tóth, L., Kele, Z., Kocsubé, S., et al. (2019). Solution structure and novel insights into phylogeny and mode of action of the Neosartorya (Aspergillus) fischeri antifungal protein (NFAP). Int. J. Biol. Macromol. 129, 511-522. doi: 10.1016/j.ijbiomac.2019.02.016

Håkansson, J., Ringstad, L., Umerska, A., Johansson, J., Andersson, T., Boge, L., et al. (2019). Characterization of the in vitro, ex vivo, and in vivo efficacy of the antimicrobial peptide DPK-060 used for topical treatment. Front. Cell. Infect. Microbiol. 9:174. doi: 10.3389/fcimb.2019.00174

Hancock, R. E. W., and Patrzykat, A. (2002). Clinical development of cationic antimicrobial peptides: from natural to novel antibiotics. Curr. Drug Targets Infect. Disord. 2, 79-83. doi: 10.2174/1568005024605855

Hayes, B. M. E., Bleackley, M. R., Anderson, M. A., and van der Weerden, N. L. (2018). The plant defensin NaD1 enters the cytoplasm of Candida albicans via endocytosis. J. Fungi 4:20. doi: 10.3390/jof4010020

Hayes, B. M. E., Bleackley, M. R., Wiltshire, J. L., Anderson, M. A., Traven, A., and van der Weerden, N. L. (2013). Identification and mechanism of action of the plant defensin $\mathrm{NaD} 1$ as a new member of the antifungal drug arsenal against Candida albicans. Antimicrob. Agents Chemother. 57, 3667-3675. doi: 10.1128/AAC.00365-13

Helmerhorst, E. J., Breeuwer, P., Van't Hof, W., Walgreen-Weterings, E., Oomen, L. C. J. M., Veerman, E. C. I., et al. (1999). The cellular target of histatin 5 on Candida albicans is the energized mitochondrion. J. Biol. Chem. 274, 7286-7291. doi: 10.1074/jbc.274.11.7286

Helmerhorst, E. J., Venuleo, C., Beri, A., and Oppenheim, F. G. (2005). Candida glabrata is unusual with respect to its resistance to cationic antifungal proteins. Yeast 22, 705-714. doi: 10.1002/yea.1241

Henninot, A., Collins, J. C., and Nuss, J. M. (2018). The current state of peptide drug discovery: back to the future? J. Med. Chem. 61, 1382-1414. doi: 10.1021/ acs.jmedchem.7b00318

Henriques, S. T., Huang, Y. H., Castanho, M. A. R. B., Bagatolli, L. A., Sonza, S., Tachedjian, G., et al. (2012). Phosphatidylethanolamine binding is a conserved feature of cyclotide-membrane interactions. J. Biol. Chem. 287, 33629-33643. doi: 10.1074/jbc.M112.372011

Hollmann, A., Martinez, M., Maturana, P., Semorile, L. C., and Maffia, P. C. (2018). Antimicrobial peptides: interaction with model and biological membranes and synergism with chemical antibiotics. Front. Chem. 6:204. doi: 10.3389/fchem. 2018.00204

Holzknecht, J., Kühbacher, A., Papp, C., Farkas, A., Váradi, G., Marcos, J. F., et al. (2020). The Penicillium chrysogenum Q176 antimicrobial protein PAFC effectively inhibits the growth of the opportunistic human pathogen Candida albicans. J. Fungi 6:141. doi: 10.3390/jof6030141

Huber, A., Galgóczy, L., Váradi, G., Holzknecht, J., Kakar, A., Malanovic, N., et al. (2020). Two small, cysteine-rich and cationic antifungal proteins from Penicillium chrysogenum: a comparative study of PAF and PAFB. Biochim. Biophys. Acta Biomembr. 1862:183246. doi: 10.1016/j.bbamem.2020.18 3246

Huber, A., Hajdu, D., Bratschun-Khan, D., Gáspári, Z., Varbanov, M., Philippot, S., et al. (2018). New antimicrobial potential and structural properties of PAFB: a cationic, cysteine-rich protein from Penicillium chrysogenum Q176. Sci. Rep. 8:1751. doi: 10.1038/s41598-018-20002-2

Huber, A., Oemer, G., Malanovic, N., Lohner, K., Kovács, L., Salvenmoser, W., et al. (2019). Membrane sphingolipids regulate the fitness and antifungal protein susceptibility of Neurospora crassa. Front. Microbiol. 10:605. doi: 10.3389/fmicb. 2019.00605

Hummel, G., Reineke, U., and Reimer, U. (2006). Translating peptides into small molecules. Mol. Biosyst. 2, 499-508. doi: 10.1039/b611791k

Hurst, L. R., and Fratti, R. A. (2020). Lipid rafts, sphingolipids, and ergosterol in yeast vacuole fusion and maturation. Front. Cell Dev. Biol. 8:539. doi: 10.3389/ fcell.2020.00539

Ikonomova, S. P., Moghaddam-Taaheri, P., Wang, Y., Doolin, M. T., Stroka, K. M., Hube, B., et al. (2020). Effects of histatin 5 modifications on antifungal activity and kinetics of proteolysis. Prot. Sci. 29, 480-493. doi: 10.1002/pro.3767

Imura, Y., Choda, N., and Matsuzaki, K. (2008). Magainin 2 in action: distinct modes of membrane permeabilization in living bacterial and mammalian cells. Biophys. J. 95, 5757-5765. doi: 10.1529/biophysj.108.133488

Jang, W. S., Bajwa, J. S., Sun, J. N., and Edgerton, M. (2010). Salivary histatin 5 internalization by translocation, but not endocytosis, is required for fungicidal activity in Candida albicans. Mol. Microbiol. 77, 354-370. doi: 10.1111/j.13652958.2010.07210.x

Janssen, B. J. C., Schirra, H. J., Lay, F. T., Anderson, M. A., and Craik, D. J. (2003). Structure of petunia hybrida defensin 1, a novel plant defensin with five disulfide bonds. Biochemistry 42, 8214-8222. doi: 10.1021/bi03 4379 o

Järvå, M., Lay, F. T., Hulett, M. D., and Kvansakul, M. (2017). Structure of the defensin NsD7 in complex with PIP2 reveals that defensin : lipid oligomer topologies are dependent on lipid type. FEBS Lett. 591, 2482-2490. doi: 10.1002/ 1873-3468.12761

Järvå, M., Lay, F. T., Phan, T. K., Humble, C., Poon, I. K. H., Bleackley, M. R., et al. (2018a). X-Ray structure of a carpet-like antimicrobial defensin-phospholipid membrane disruption complex. Nat. Commun. 9:1962. doi: 10.1038/s41467018-04434-y

Järvå, M., Phan, T. K., Lay, F. T., Caria, S., Kvansakul, M., and Hulett, M. D. (2018b). Human-defensin 2 kills Candida albicans through phosphatidylinositol 4,5-bisphosphate-mediated membrane permeabilization. Sci. Adv. 4, 979-1004. doi: 10.1126/sciadv.aat0979

Joly, S., Maze, C., McCray, P. B., and Guthmiller, J. M. (2004). Human $\beta$-defensins 2 and 3 demonstrate strain-selective activity against oral microorganisms. J. Clin. Microbiol. 42, 1024-1029. doi: 10.1128/JCM.42.3.1024-29

Jung, S. I., Finkel, J. S., Solis, N. V., Chaili, S., Mitchell, A. P., Yeaman, M. R., et al. (2013). Bcrl functions downstream of Ssd1 to mediate antimicrobial peptide resistance in Candida albicans. Eukaryot. Cell 12, 411-419. doi: 10.1128/EC. 00285- 12

Kaiserer, L., Oberparleiter, C., Weiler-Görz, R., Burgstaller, W., Leiter, E., and Marx, F. (2003). Characterization of the Penicillium chrysogenum antifungal protein PAF. Arch. Microbiol. 180, 204-210. doi: 10.1007/s00203-0030578-8

Kim, J. Y. (2016). Human fungal pathogens: why should we learn? Korea J. Microbiol. 54, 145-148. doi: 10.1007/s12275-016-0647-8

Kinjo, T. G., and Schnetkamp, P. P. M. (2005). " $\mathrm{Ca}^{2+}$ chemistry, storage and transport in biologic systems," in Voltage-Gated Calcium Channels. Molecular 
Biology Intelligence Unit, (Boston, MA: Springer). doi: 10.1007/0-387-275 26-6_1

Kohler, V., Aufschnaiter, A., and Büttner, S. (2020). Closing the gap: membrane contact sites in the regulation of autophagy. Cells 9:1184. doi: 10.3390/ cells9051184

Kojic, E. M., and Darouiche, R. O. (2004). Candida infections of medical devices. Clin. Microbiol. Rev. 17, 255-267. doi: 10.1128/CMR.17.2.255-267.2004

Koshlukova, S. E., Lloyd, T. L., Araujo, M. W. B., and Edgerton, M. (1999). Salivary histatin 5 induces non-lytic release of ATP from Candida albicans leading to cell death. J. Biol. Chem. 274, 18872-18879. doi: 10.1074/jbc.274.27.18872

Kovács, L., Virágh, M., Takó, M., Papp, T., Vágvölgyi, C., and Galgóczy, L. (2011). Isolation and characterization of Neosartorya fischeri antifungal protein (NFAP). Peptides 32, 1724-1731. doi: 10.1016/j.peptides.2011.06.022

Kovács, R., Holzknecht, J., Hargitai, Z., Papp, C., Farkas, A., Borics, A., et al. (2019). In vivo applicability of Neosartorya fischeri antifungal protein 2 (NFAP2) in treatment of vulvovaginal candidiasis. Antimicrob. Agents Chemother. 63:e01777-18. doi: 10.1128/AAC.01777-18

Kovács, R., Nagy, F., Tóth, Z., Forgács, L., Tóth, L., Váradi, G., et al. (2021). The Neosartorya fischeri antifungal protein 2 (NFAP2): a new potential weapon against multidrug-resistant Candida auris biofilms. Int. J. Mol. Sci. 22:771. doi: 10.3390/ijms22020771

Krishnakumari, V., Rangaraj, N., and Nagaraj, R. (2009). Antifungal activities of human beta-defensins hBD-1 to hBD-3 and their C-terminal analogs Phd1 to Phd3. Antimicrob. Agents Chemother. 53, 256-260. doi: 10.1128/AAC.00470-08

Kumar, P., Kizhakkedathu, J. N., and Straus, S. K. (2018). Antimicrobial peptides: diversity, mechanism of action and strategies to improve the activity and biocompatibility in vivo. Biomolecules 8:4. doi: 10.3390/biom8010004

Kumar, R., Chadha, S., Saraswat, D., Bajwa, J. S., Li, R. A., Conti, H. R., et al. (2011). Histatin 5 uptake by Candida albicans utilizes polyamine transporters Dur3 and Dur31 proteins. J. Biol. Chem. 286, 43748-43758. doi: 10.1074/jbc.M111.31 1175

Kvansakul, M., Lay, F. T., Adda, C. G., Veneer, P. K., Baxter, A. A., Phan, T. K., et al. (2016). Binding of phosphatidic acid by NsD7 mediates the formation of helical defensin-lipid oligomeric assemblies and membrane permeabilization. Proc. Nat. Acad. Sci. U.S.A. 113, 11202-11207. doi: 10.1073/pnas. 1607855113

Lai, R., Liu, H., Lee, W. H., and Zhang, Y. (2002). An anionic antimicrobial peptide from toad Bombina maxima. Biochem. Biophys. Res. Commun. 295, 796-799. doi: 10.1016/S0006-291X(02)00762-3

Lamberty, M., Caille, A., Landon, C., Tassin-Moindrot, S., Hetru, C., Bulet, P., et al. (2001a). Solution structures of the antifungal heliomicin and a selected variant with both antibacterial and antifungal activities. Biochemistry 40, 11995-12003. doi: 10.1021/bi0103563

Lamberty, M., Zachary, D., Lanot, R., Bordereau, C., Robert, A., Hoffmann, J. A., et al. (2001b). Insect immunity. Constitutive expression of a cysteine-rich antifungal and a linear antibacterial peptide in a termite insect. J. Biol. Chem. 276, 4085-4092. doi: 10.1074/jbc.M002998200

Landon, C., Barbault, F., Legrain, M., Menin, L., Guenneugues, M., Schott, V., et al. (2003). Lead optimization of antifungal peptides with 3D NMR structures analysis. Protein Sci. 13, 703-713. doi: 10.1110/ps.03404404

Landon, C., Sodano, P., Hetru, C., Hoffmann, J., and Ptak, M. (1997). Solution structure of drosomycin, the first inducible antifungal protein from insects. Protein Sci. 6, 1878-1884. doi: 10.1002/pro.5560060908

Lang, A. B., Peter, A. T. J., Walter, P., and Kornmann, B. (2015). ER-mitochondrial junctions can be bypassed by dominant mutations in the endosomal protein Vps13. J. Cell Biol. 210, 883-890. doi: 10.1083/jcb.201502105

Lay, F. T., and Anderson, M. A. (2005). Defensins - components of the innate immune system in plants. Curr. Protein Pept. Sci. 6, 85-101. doi: 10.2174/ 1389203053027575

Lay, F. T., Mills, G. D., Poon, I. K. H., Cowieson, N. P., Kirby, N. K., Baxter, A. A., et al. (2012). Dimerization of plant defensin NaD1 enhances its antifungal activity. J. Biol. Chem. 287, 19961-19972. doi: 10.1074/jbc.M111.331009

Lay, F. T., Schirra, H. J., Scanlon, M. J., Anderson, M. A., and Craik, D. J. (2003). The three-dimensional solution structure of NaD1, a new floral defensin from Nicotiana alata and its application to a homology model of the crop defense protein alfAFP. J. Mol. Biol. 325, 175-188. doi: 10.1016/S0022-2836(02)01103-8

Lazzaro, B. P., Zasloff, M., and Rolff, J. (2020). Antimicrobial peptides: application informed by evolution. Science 368:5480. doi: 10.1126/science.aau5480

Lee, D. G., Kim, H. K., Kim, S. A., Park, Y., Park, S. C., Jang, S. H., et al. (2003). Fungicidal effect of indolicidin and its interaction with phospholipid membranes. Biochem. Biophys. Res. Commun. 305, 305-310. doi: 10.1016/ s0006-291x(03)00755-1

Lee, H., Hwang, J. S., and Lee, D. G. (2016). Scolopendin 2 leads to cellular stress response in Candida albicans. Apoptosis 21, 856-865. doi: 10.1007/s10495-0161254-1

Lee, H., Hwang, J. S., and Lee, D. G. (2017). Scolopendin, an antimicrobial peptide from centipede, attenuates mitochondrial functions and triggers apoptosis in Candida albicans. Biochem. J. 474, 635-645. doi: 10.1042/BCJ20161039

Lee, I. H., Zhao, C., Cho, Y., Harwig, S. S. L., Cooper, E. L., and Lehrer, R. I. (1997). Clavanins, $\alpha$-helical antimicrobial peptides from tunicate hemocytes. FEBS Lett. 400, 158-162. doi: 10.1016/S0014-5793(96)01374-9

Lee, J., Hwang, J. S., Hwang, I. S., Cho, J., Lee, E., Kim, Y., et al. (2012). Coprisin-induced antifungal effects in Candida albicans correlate with apoptotic mechanisms. Free Radic. Biol. Med. 52, 2302-2311. doi: 10.1016/j. freeradbiomed.2012.03.012

Lee, J., Lee, D., Choi, H., Kim, H. H., Kim, H., Hwang, J. S., et al. (2014). Structureactivity relationships of the intramolecular disulfide bonds in coprisin, a defensin from the dung beetle. BMB Rep. 47, 625-630. doi: 10.5483/BMBRep. 2014.47.11.262

Lehrer, R. I., Ganz, T., Szklarek, D., and Selsted, M. E. (1988). Modulation of the in vitro candidacidal activity of human neutrophil defensins by target cell metabolism and divalent cations. J. Clin. Invest. 81, 1829-1835. doi: 10.1172/ JCI113527

Leiter, É, Szappanos, H., Oberparleiter, C., Kaiserer, L., Csernoch, L., Pusztahelyi, T., et al. (2005). Antifungal protein PAF severely affects the integrity of the plasma membrane of Aspergillus nidulans and induces an apoptosis-like phenotype. Antimicrob. Agents Chemother. 49, 2445-2453. doi: 10.1128/AAC. 49.6.2445-2453.2005

Li, H., Velivelli, S. L. S., and Shah, D. M. (2019). Antifungal potency and modes of action of a novel olive tree defensin against closely related ascomycete fungal pathogens. Mol. Plant Microbe Interact. 32, 1649-1664. doi: 10.1094/MPMI-0819-0224-R

Li, X. S., Reddy, M. S., Baev, D., and Edgerton, M. (2003). Candida albicans Ssa1/2p is the cell envelope binding protein for human salivary histatin 5. J. Biol. Chem. 278, 28553-28561. doi: 10.1074/jbc.M300680200

Liu, L., Roberts, A. A., and Ganz, T. (2003). By IL-1 signaling, monocytederived cells dramatically enhance the epidermal antimicrobial response to lipopolysaccharide. J. Immunol. 170, 575-580. doi: 10.4049/jimmunol.170.1.575

Liu, Y., and Levine, B. (2015). Autosis and autophagic cell death: the dark side of autophagy. Cell Death Differ. 22, 367-376. doi: 10.1038/cdd.2014.143

Lobo, D. S., Pereira, I. B., Fragel-Madeira, L., De Medeiros, L. N., Cabral, L. M., Faria, J., et al. (2007). Antifungal Pisum sativum defensin 1 interacts with Neurospora crassa cyclin F related to the cell cycle. Biochemistry 46, 987-996. doi: $10.1021 /$ bi061441j

Lockhart, S. R., Etienne, K. A., Vallabhaneni, S., Farooqi, J., Chowdhary, A., Govender, N. P., et al. (2017). Simultaneous emergence of multidrug-resistant Candida auris on 3 continents confirmed by whole-genome sequencing and epidemiological analyses. Clin. Infect. Dis. 64, 134-140. doi: 10.1093/cid/ciw691

López-García, B., Lee, P. H. A., Yamasaki, K., and Gallo, R. L. (2005). Antifungal activity of cathelicidins and their potential role in Candida albicans skin infection. J. Invest. Dermatol. 125, 108-115. doi: 10.1111/j.0022-202X.2005. 23713.x

Manners, J. M., Penninckx, I. A. M. A., Vermaere, K., Kazan, K., Brown, R. L., Morgan, A., et al. (1998). The promoter of the plant defensin gene PDF1.2 from Arabidopsis is systemically activated by fungal pathogens and responds to methyl jasmonate but not to salicylic acid. Plant Mol. Biol. 38, 1071-1080. doi: 10.1023/A:1006070413843

Martinez Del, Pozo, A., Lacadena, V., Mancheno, J. M., Olmo, N., Onaderra, M., et al. (2002). The antifungal protein AFP of Aspergillus giganteus is an oligonucleotide/oligosaccharide binding (OB) fold-containing protein that produces condensation of DNA. J. Biol. Chem. 277, 46179-46183. doi: 10.1074/ jbc.M207472200

Martínez-Muñoz, G. A., and Kane, P. (2008). Vacuolar and plasma membrane proton pumps collaborate to achieve cytosolic $\mathrm{pH}$ homeostasis in yeast. J. Biol. Chem. 283, 7743-7743. doi: 10.1074/jbc.M710470200

McCaslin, T. G., Pagba, C. V., Yohannan, J., and Barry, B. A. (2019). Specific metallo-protein interactions and antimicrobial activity in histatin 5, an intrinsically disordered salivary peptide. Sci. Rep. 9:17303. doi: 10.1038/s41598019-52676-7 
McGregor, D. P. (2008). Discovering and improving novel peptide therapeutics. Curr. Opin. Pharmacol. 8, 616-619. doi: 10.1016/j.coph.2008.06.002

Mello, ÉO., Ribeiro, S. F. F., Carvalho, A. O., Santos, I. S., Da Cunha, M., SantaCatarina, C., et al. (2011). Antifungal activity of PvD1 defensin involves plasma membrane permeabilization, inhibition of medium acidification, and induction of ROS in fungi cells. Curr. Microbiol. 62, 1209-1217. doi: 10.1007/s00284-0109847-3

Mello, ÉO., Santos, I. S., Carvalho, A. O., Souza, L. S., Souza-Filho, G. A., Nascimento, V. V., et al. (2014). Functional expression and activity of the recombinant antifungal defensin PvD1r from Phaseolus vulgaris L. (common bean) seeds. BMC Biochem. 15:7. doi: 10.1186/1471-2091-15-7

Mercier, T., Guldentops, E., Lagrou, K., and Maertens, J. (2018). Galactomannan, a surrogate marker for outcome in invasive aspergillosis: finally coming of age. Front. Microbiol. 9:661. doi: 10.3389/fmicb.2018.00661

Molino, D., Nascimbeni, A. C., Giordano, F., Codogno, P., and Morel, E. (2017). ER-driven membrane contact sites: evolutionary conserved machineries for stress response and autophagy regulation? Commun. Integr. Biol. 10:e1401699. doi: 10.1080/19420889.2017.1401699

Mookherjee, N., Anderson, M. A., Haagsman, H. P., and Davidson, D. J. (2020). Antimicrobial host defence peptides: functions and clinical potential. Nat. Rev. Drug Discov. 19, 311-332. doi: 10.1038/s41573-019-0058-8

Moreno, A. B., Martínez Del, Pozo, A., and San Segundo, B. (2006). Biotechnologically relevant enzymes and proteins. Antifungal mechanism of the Aspergillus giganteus AFP against the rice blast fungus Magnaporthe grisea. Appl. Microbiol. Biotechnol. 72, 883-895. doi: 10.1007/s00253-006-0362-1

Morton, C. O., Hayes, A., Wilson, M., Rash, B. M., Oliver, S. G., and Coote, P. (2007). Global phenotype screening and transcript analysis outlines the inhibitory mode(s) of action of two amphibian-derived, alpha-helical, cationic peptides on Saccharomyces cerevisiae. Antimicrob. Agents Chemother. 51, 39483959. doi: 10.1128/AAC.01007-07

Muñoz, A., Chu, M., Marris, P. I., Sagaram, U. S., Kaur, J., Shah, D. M., et al. (2014). Specific domains of plant defensins differentially disrupt colony initiation, cell fusion and calcium homeostasis in Neurospora crassa. Mol. Microbiol. 92, 1357-1374. doi: 10.1111/mmi.12634

Muñoz, A., López-García, B., and Marcos, J. F. (2007). Comparative study of antimicrobial peptides to control citrus postharvest decay caused by Penicillium digitatum. J. Agric. Food Chem. 55, 8170-8176. doi: 10.1021/jf0718143

Narayan, K., and Lemmon, M. A. (2006). Determining selectivity of phosphoinositide-binding domains. Methods 39, 122-133. doi: 10.1016/j. ymeth.2006.05.006

Nascimbeni, A. C., Giordano, F., Dupont, N., Grasso, D., Vaccaro, M. I., Codogno, P., et al. (2017). ER-plasma membrane contact sites contribute to autophagosome biogenesis by regulation of local PI3P synthesis. EMBO J. 36, 2018-2033. doi: 10.15252/embj.201797006

Noble, S. M., French, S., Kohn, L. A., Chen, V., and Johnson, A. D. (2010). Systematic screens of a Candida albicans homozygous deletion library decouple morphogenetic switching and pathogenicity. Nat. Gen. 42, 590-598. doi: 10. 1038/ng.605

Norris, H. L., Kumar, R., Ong, C. Y., Xu, D., and Edgerton, M. (2020). Zinc binding by histatin 5 promotes fungicidal membrane disruption in C. albicans and C. glabrata. J. Fungi 6, 1-16. doi: 10.3390/jof6030124

Oberparleiter, C., Kaiserer, L., Haas, H., Ladurner, P., Andratsch, M., and Marx, F. (2003). Active internalization of the Penicillium chrysogenum antifungal protein PAF in sensitive Aspergilli. Antimicrob. Agents Chemother. 47, 3598-3601. doi: 10.1128/AAC.47.11.3598-3601.2003

Ochiai, A., Ogawa, K., Fukuda, M., Ohori, M., Kanaoka, T., Tanaka, T., et al. (2018). Rice defensin OsAFP1 is a new drug candidate against human pathogenic fungi. Sci. Rep. 8:11434. doi: 10.1038/s41598-018-29715-w

Ochiai, A., Ogawa, K., Fukuda, M., Suzuki, M., Ito, K., Tanaka, T., et al. (2020). Crystal structure of rice defensin OsAFP1 and molecular insight into lipidbinding. J. Biosci. Bioeng. 130, 6-13. doi: 10.1016/j.jbiosc.2020.02.011

O’Neil, D. A., Porter, E. M., Elewaut, D., Anderson, G. M., Eckmann, L., Ganz, T., et al. (1999). Expression and regulation of the human beta-defensins hBD-1 and hBD-2 in intestinal epithelium. J. Immunol. 163, 6718-6724.

Ordonez, S. R., Amarullah, I. H., Wubbolts, R. W., Veldhuizen, E. J. A., and Haagsman, H. P. (2014). Fungicidal mechanisms of cathelicidins LL-37 and CATH-2 revealed by live-cell imaging. Antimicr. Agents Chemother. 58, 22402248. doi: 10.1128/AAC.01670-13
Osborn, R. W., De Samblanx, G. W., Thevissen, K., Goderis, I., Torrekens, S., Van Leuven, F., et al. (1995). Isolation and characterisation of plant defensins from seeds of Asteraceae, Fabaceae, Hippocastanaceae and Saxifragaceae. FEBS Lett. 368, 257-262. doi: 10.1016/0014-5793(95)00666-W

Oudhoff, M. J., Bolscher, J. G. M., Nazmi, K., Kalay, H., Van't Hof, W., Amerongen, A. V. N., et al. (2008). Histatins are the major wound-closure stimulating factors in human saliva as identified in a cell culture assay. FASEB J. 22, 3805-3812. doi: 10.1096/fj.08-112003

Paege, N., Warnecke, D., Zäuner, S., Hagen, S., Rodrigues, A., Baumann, B., et al. (2019). Species-specific differences in the susceptibility of fungi to the antifungal protein AFP depend on C-3 saturation of glycosylceramides. mSphere 4:e0074119. doi: 10.1128/mSphere.00741-19

Parisi, K., Doyle, S. R., Lee, E., Lowe, R. G. T., van der Weerden, N. L., Anderson, M. A., et al. (2019a). Screening the Saccharomyces cerevisiae nonessential gene deletion library reveals diverse mechanisms of action for antifungal plant defensins. Antimicr. Agents Chemother. 63:e01097-19. doi: 10.1128/AAC. 01097- 19

Parisi, K., Shafee, T. M. A., Quimbar, P., van der Weerden, N. L., Bleackley, M. R., and Anderson, M. A. (2019b). The evolution, function and mechanisms of action for plant defensins. Semin. Cell Dev. Biol. 88, 107-118. doi: 10.1016/j. semcdb.2018.02.004

Park, C., and Lee, D. G. (2010). Melittin induces apoptotic features in Candida albicans. Biochem. Biophys. Res. Commun. 394, 170-172. doi: 10.1016/j.bbrc. 2010.02.138

Parvy, J. P., Yu, Y., Dostalova, A., Kondo, S., Kurjan, A., Bulet, P., et al. (2019). The antimicrobial peptide defensin cooperates with tumour necrosis factor to drive tumour cell death in Drosophila. eLife 8:e45061. doi: 10.7554/eLife.45061

Pathirana, R. U., Friedman, J., Norris, H. L., Salvatori, O., McCall, A. D., Kay, J., et al. (2018). Fluconazole-resistant Candida auris is susceptible to salivary histatin 5 killing and to intrinsic host defenses. Antimicr. Agents Chemother. 62:e01872-17. doi: 10.1128/AAC.01872-17

Paulsen, V. S., Blencke, H. M., Benincasa, M., Haug, T., Eksteen, J. J., Styrvold, O. B., et al. (2013). Structure-activity relationships of the antimicrobial peptide arasin 1 - and mode of action studies of the N-terminal, proline-rich region. PLoS One 8:e53326. doi: 10.1371/journal.pone.0053326

Payne, J. A. E., Bleackley, M. R., Lee, T. H., Shafee, T. M. A., Poon, I. K. H., Hulett, M. D., et al. (2016). The plant defensin NaD1 introduces membrane disorder through a specific interaction with the lipid, phosphatidylinositol 4,5 bisphosphate. Biochim. Biophys. Acta Biomembr. 1858, 1099-1109. doi: 10.1016/ j.bbamem.2016.02.016

Penninckx, I. A., Eggermont, K., Terras, F. R., Thomma, B. P., De Samblanx, G. W., Buchala, A., et al. (1996). Pathogen-induced systemic activation of a plant defensin gene in Arabidopsis follows a salicylic acid-independent pathway. Plant Cell 8, 2309-2323. doi: 10.1105/tpc.8.12.2309

Phan, T. K., Lay, F. T., Poon, I. K. H., Hinds, M. G., Kvansakul, M., and Hulett, M. D. (2016). Human $\beta$-defensin 3 contains an oncolytic motif that binds $\mathrm{PI}(4,5) \mathrm{P}_{2}$ to mediate tumour cell permeabilisation. Oncotarget 7, 2054-2069. doi: 10.18632 /oncotarget.6520

Phillips, M. J., and Voeltz, G. K. (2016). Structure and function of ER membrane contact sites with other organelles. Nat. Rev. Mol. Cell Biol. 17, 69-82. doi: 10.1038/nrm.2015.8

Poon, I. K. H., Baxter, A. A., Lay, F. T., Mills, G. D., Adda, C. G., Payne, J. A. E., et al. (2014). Phosphoinositide-mediated oligomerization of a defensin induces cell lysis. eLife 3:e01808. doi: 10.7554/eLife.01808

Promore Pharma (2021). Ropocamptide - Healing of Chronic Wounds. Available online at: https://www.promorepharma.com/en/ll-37-healing-of-chronicwounds/ (accessed on 24 February 2021)

Puri, S., and Edgerton, M. (2014). How does it kill?: understanding the candidacidal mechanism of salivary histatin 5. Eukaryot. Cell 13, 958-964. doi: 10.1128/EC. 00095-14

Ramamoorthy, V., Cahoon, E. B., Thokala, M., Minto, R. E., and Shah, D. M. (2007). Glucosylceramide synthase is essential for alfalfa defensinmediated growth inhibition but not for pathogenicity of Fusarium graminearum. Mol. Microbiol. 66, 771-786. doi: 10.1111/j.1365-2958.2007.05 955.x

Redza-Dutordoir, M., and Averill-Bates, D. A. (2016). Activation of apoptosis signalling pathways by reactive oxygen species. Biochim. Biophys. Acta Mol. Cell Res. 1863, 2977-2992. doi: 10.1016/j.bbamcr.2016.09.012 
Rego, A., Trindade, D., Chaves, S. R., Manon, S., Costa, V., Sousa, M. J., et al. (2014). The yeast model system as a tool towards the understanding of apoptosis regulation by sphingolipids. FEMS Yeast Res. 14, 160-178. doi: 10.1111/15671364.12096

Revie, N. M., Iyer, K. R., Robbins, N., and Cowen, L. E. (2018). Antifungal drug resistance: evolution, mechanisms and impact. Curr. Opin. Microb. 45, 70-76. doi: 10.1016/j.mib.2018.02.005

Rodrigues, M. L., Travassos, L. R., Miranda, K. R., Franzen, A. J., Rozental, S., de Souza, W., et al. (2000). Human antibodies against a purified glucosylceramide from Cryptococcus neoformans inhibit cell budding and fungal growth. Infect. Immun. 68, 7049-7060. doi: 10.1128/IAI.68.12.7049-7060.2000

Sagaram, U. S., El-Mounadi, K., Buchko, G. W., Berg, H. R., Kaur, J., Pandurangi, R. S., et al. (2013). Structural and functional studies of a phosphatidic acidbinding antifungal plant defensin MtDef4: identification of an RGFRRR motif governing fungal cell entry. PLoS One 8:e82485. doi: 10.1371/journal.pone. 0082485

Sagaram, U. S., Pandurangi, R., Kaur, J., Smith, T. J., and Shah, D. M. (2011). Structure-activity determinants in antifungal plant defensins Msdef1 and Mtdef4 with different modes of action against Fusarium graminearum. PLoS One 6:e18550. doi: 10.1371/journal.pone.0018550

Saito, K., Takakuwa, N., Ohnishi, M., and Oda, Y. (2006). Presence of glucosylceramide in yeast and its relation to alkali tolerance of yeast. Appl. Microbiol. Biotechnol. 71, 515-521. doi: 10.1007/s00253-005-0187-3

Sampaio-Marques, B., Burhans, W. C., and Ludovico, P. (2019). Yeast at the forefront of research on ageing and age-related diseases. Prog. Mol. Subcell. Biol. 58, 217-242. doi: 10.1007/978-3-030-13035-0_9

Sardar, A. H., Das, S., Agnihorti, S., Kumar, M., Ghosh, A. K., Abhishek, K., et al. (2013). Spinigerin induces apoptotic like cell death in a caspase independent manner in Leishmania donovani. Exp. Parasitol. 135, 715-725. doi: 10.1016/j. exppara.2013.10.011

Sathoff, A. E., Velivelli, S., Shah, D. M., and Samac, D. A. (2019). Plant defensin peptides have antifungal and antibacterial activity against human and plant pathogens. Phytopathology 109, 402-408. doi: 10.1094/PHYTO-09-18-0331-R

Scarsini, M., Tomasinsig, L., Arzese, A., D’Este, F., Oro, D., and Skerlavaj, B. (2015). Antifungal activity of cathelicidin peptides against planktonic and biofilm cultures of Candida species isolated from vaginal infections. Peptides 71, 211-221. doi: 10.1016/j.peptides.2015.07.023

Schittek, B., Hipfel, R., Sauer, B., Bauer, J., Kalbacher, H., Stevanovic, S., et al. (2001). Dermcidin: a novel human antibiotic peptide secreted by sweat glands. Nat. Immunol. 2, 1133-1137. doi: 10.1038/ni732

Scorrano, L., De Matteis, M. A., Emr, S., Giordano, F., Hajnóczky, G., Kornmann, B., et al. (2019). Coming together to define membrane contact sites. Nat. Commun. 10:1287. doi: 10.1038/s41467-019-09253-3

Shah, P., Hsiao, F. S. H., Ho, Y. H., and Chen, C. S. (2016). The proteome targets of intracellular targeting antimicrobial peptides. Proteomics 16, 1225-1237. doi: 10.1002/pmic. 201500380

Shah, P., Wu, W. S., and Chen, C. S. (2019). Systematical analysis of the protein targets of lactoferricin B and histatin 5 using yeast proteome microarrays. Int. J. Mol. Sci. Art. 20, 4218-4238. doi: 10.3390/ijms20174218

Shin, S. Y., Kang, S. W., Lee, D. G., Eom, S. H., Song, W. K., and Kim, J. I. (2000). CRAMP analogues having potent antibiotic activity against bacterial, fungal, and tumor cells without hemolytic activity. Biochem. Biophys. Res. Commun. 275, 904-909. doi: 10.1006/bbrc.2000.3269

Silvestro, L., Weiser, J. N., and Axelsen, P. H. (2000). Antibacterial and antimembrane activities of cecropin A in Escherichia coli. Antimicr. Agents Chemother. 44, 602-607. doi: 10.1128/AAC.44.3.602-607.2000

Simon, A., Kullberg, B. J., Tripet, B., Boerman, O. C., Zeeuwen, P., van der VenJongekrijg, J., et al. (2008). Drosomycin-like defensin, a human homologue of Drosophila melanogaster drosomycin with antifungal activity. Antimicrob. Agents Chemother. 52, 1407-1412. doi: 10.1128/AAC.00155-07

Slazak, B., Kapusta, M., Strömstedt, A. A., Słomka, A., Krychowiak, M., Shariatgorji, M., et al. (2018). How does the sweet violet (Viola odorata L.) fight pathogens and pests - cyclotides as a comprehensive plant host defense system. Front. Plant Sci. 9:1296. doi: 10.3389/fpls.2018.01296

Soares, J. R., de Melo, E. J. T., Cunha, M., Fernandes, K. V. S., Taveira, G. B., Pereira, L. S., et al. (2017). Interaction between the plant ApDef1 defensin and Saccharomyces cerevisiae results in yeast death through a cell cycleand caspase-dependent process occurring via uncontrolled oxidative stress.
Biochim. Biophys. Acta Gen. Subj. 1861, 3429-3443. doi: 10.1016/j.bbagen.2016. 09.005

Sørensen, O. E., Cowland, J. B., Theilgaard-Mönch, K., Liu, L., Ganz, T., and Borregaard, N. (2003). Wound healing and expression of antimicrobial peptides/polypeptides in human keratinocytes, a consequence of common growth factors. J. Immunol. 170, 5583-5589. doi: 10.4049/jimmunol.170.11. 5583

Spitzer, M., Robbins, N., and Wright, G. D. (2017). Combinatorial strategies for combating invasive fungal infections. Virulence 8, 169-185. doi: 10.1080/ 21505594.2016.1196300

Steiner, H., Hultmark, D., Engström, Å, Bennich, H., and Boman, H. G. (1981). Sequence and specificity of two antibacterial proteins involved in insect immunity. Nature 292, 246-248. doi: 10.1038/292246a0

Struyfs, C., Cools, T. L., De Cremer, K., Sampaio-Marques, B., Ludovico, P., Wasko, B. M., et al. (2020). The antifungal plant defensin HsAFP1 induces autophagy, vacuolar dysfunction and cell cycle impairment in yeast. Biochim. Biophys. Acta Biomembr. 1862:183255. doi: 10.1016/j.bbamem.2020.183255

Tam, J. P., Lu, Y. A., Yang, J. L., and Chiu, K. W. (1999). An unusual structural motif of antimicrobial peptides containing end-to-end macrocycle and cystineknot disulfides. Proc. Nat. Acad. Sci. U.S.A. 96, 8913-8918. doi: 10.1073/pnas. 96.16.8913

Tavares, P. M., Thevissen, K., Cammue, B. P. A., François, I. E. J. A., BarretoBergter, E., Taborda, C. P., et al. (2008). In vitro activity of the antifungal plant defensin RsAFP2 against Candida isolates and its in vivo efficacy in prophylactic murine models of candidiasis. Antimicr. Agents Chemother. 52, 4522-4525. doi: 10.1128/AAC.00448-08

Teixeira, V., Feio, M. J., and Bastos, M. (2012). Role of lipids in the interaction of antimicrobial peptides with membranes. Prog. Lipid Res. 51, 149-177. doi: 10.1016/j.plipres.2011.12.005

Terras, F. R. G., Eggermont, K., Kovaleva, V., Raikhel, N. V., Osborn, R. W., Kester, A., et al. (1995). Small cysteine-rich antifungal proteins from radish: their role in host defense. Plant Cell 7, 573-588. doi: 10.1105/tpc.7.5.573

Thapa, R. K., Diep, D. B., and Tønnesen, H. H. (2020). Topical antimicrobial peptide formulations for wound healing: current developments and future prospects. Acta Biomater. 103, 52-67. doi: 10.1016/j.actbio.2019.12. 025

Theis, T., Marx, F., Salvenmoser, W., Stahl, U., and Meyer, V. (2005). New insights into the target site and mode of action of the antifungal protein of Aspergillus giganteus. Res. Microbiol. 156, 47-56. doi: 10.1016/j.resmic.2004.08.006

Theis, T., Wedde, M., Meyer, V., and Stahl, U. (2003). The antifungal protein from Aspergillus giganteus causes membrane permeabilization. Antimicrob. Agents Chemother. 47, 588-593. doi: 10.1128/aac.47.2.588-593.2003

Thevissen, K., Cammue, B. P. A., Lemaire, K., Winderickx, J., Dickson, R. C., Lester, R. L., et al. (2000a). A gene encoding a sphingolipid biosynthesis enzyme determines the sensitivity of Saccharomyces cerevisiae to an antifungal plant defensin from dahlia (Dahlia merckii). Proc. Nat. Acad. Sci. U.S.A. 97, 9531-9536. doi: 10.1073/pnas.160077797

Thevissen, K., François, I. E. J. A., Takemoto, J. Y., Ferket, K. K. A., Meert, E. M. K., and Cammue, B. P. A. (2003). DmAMP1, an antifungal plant defensin from dahlia (Dahlia merckii), interacts with sphingolipids from Saccharomyces cerevisiae. FEMS Microbiol. Lett. 226, 169-173. doi: 10.1016/S0378-1097(03) 00590-1

Thevissen, K., Ghazi, A., De Samblanx, G. W., Brownlee, C., Osborn, R. W., and Broekaert, W. F. (1996). Fungal membrane responses induced by plant defensins and thionins. J. Biol. Chem. 271, 15018-15025. doi: 10.1074/jbc.271. 25.15018

Thevissen, K., Osborn, R. W., Acland, D. P., and Broekaert, W. F. (1997). Specific, high affinity binding sites for an antifungal plant defensin on Neurospora crassa hyphae and microsomal membranes. J. Biol. Chem. 272, 32176-32181. doi: $10.1074 /$ jbc. 272.51 .32176

Thevissen, K., Osborn, R. W., Acland, D. P., and Broekaert, W. F. (2000b). Specific binding sites for an antifungal plant defensin from dahlia (Dahlia merckii) on fungal cells are required for antifungal activity. Mol. Plant Microbe Interact. 13, 54-61. doi: 10.1094/MPMI.2000.13.1.54

Thevissen, K., Tavares, P. M., Xu, D., Blankenship, J., Vandenbosch, D., IdkowiakBaldys, J., et al. (2012). The plant defensin RsAFP2 induces cell wall stress, septin mislocalization and accumulation of ceramides in Candida albicans. Mol. Microbiol. 84, 166-180. doi: 10.1111/j.1365-2958.2012.08017.x 
Thevissen, K., Terras, F. R. G., and Broekaert, W. F. (1999). Permeabilization of fungal membranes by plant defensins inhibits fungal growth. Appl. Environ. Microbiol. 65, 5451-5458. doi: 10.1128/aem.65.12.5451-5458.1999

Thevissen, K., Warnecke, D. C., François, I. E. J. A., Leipelt, M., Heinz, E., Ott, C., et al. (2004). Defensins from insects and plants interact with fungal glucosylceramides. J. Biol. Chem. 279, 3900-3905. doi: 10.1074/jbc.M311165200

Thomma, B. P. H. J., and Broekaert, W. F. (1998). Tissue-specific expression of plant defensin genes PDF2.1 and PDF2.2 in Arabidopsis thaliana. Plant Physiol. Biochem. 36, 533-537. doi: 10.1016/S0981-9428(98)80179-4

Tian, C., Gao, B., Rodriguez, M. D. C., Lanz-Mendoza, H., Ma, B., and Zhu, S. (2008). Gene expression, antiparasitic activity, and functional evolution of the drosomycin family. Mol Immunol. 45, 3909-3916. doi: 10.1016/j.molimm.2008. 06.025

Tossi, A., Sandri, L., and Giangaspero, A. (2000). Amphipathic, $\alpha$-helical antimicrobial peptides. Biopolymers 55, 4-30. doi: 10.1002/1097-0282200055: $1<4$ ::aid-bip30<3.0.co;2-m

Tóth, L., Kele, Z., Borics, A., Nagy, L. G., Váradi, G., Virágh, M., et al. (2016). NFAP2, a novel cysteine-rich anti-yeast protein from Neosartory a fischeri NRRL 181: isolation and characterization. AMB Express 6:75. doi: 10.1186/s13568016-0250-8

Tóth, L., Váradi, G., Borics, A., Batta, G., Kele, Z., Vendrinszky, Á, et al. (2018). Anti-candidal activity and functional mapping of recombinant and synthetic Neosartorya fischeri antifungal protein 2 (NFAP2). Front. Microbiol. 9:393. doi: 10.3389/fmicb.2018.00393

Tsai, P. W., Yang, C. Y., Chang, H. T., and Lan, C. Y. (2011). Human antimicrobial peptide LL-37 inhibits adhesion of Candida albicans by interacting with yeast cell-wall carbohydrates. PLoS One 6:17755. doi: 10.1371/journal.pone.0017755

Turner, J., Cho, Y., Dinh, N. N., Waring, A. J., and Lehrer, R. I. (1998). Activities of LL-37, a cathelin-associated antimicrobial peptide of human neutrophils. Antimicrob. Agents Chemother. 42, 2206-2214. doi: 10.1128/AAC.42.9.2206

van der Weerden, N. L., Bleackley, M. R., and Anderson, M. A. (2013). Properties and mechanisms of action of naturally occurring antifungal peptides. Cell Mol. Life Sci. 70, 3545-3570. doi: 10.1007/s00018-013-1260-1

van der Weerden, N. L., Hancock, R. E. W., and Anderson, M. A. (2010). Permeabilization of fungal hyphae by the plant defensin NaD1 occurs through a cell wall-dependent process. J. Biol. Chem. 285, 37513-37520. doi: 10.1074/jbc. M110.134882

van der Weerden, N. L., Lay, F. T., and Anderson, M. A. (2008). The plant defensin, $\mathrm{NaD1}$, enters the cytoplasm of Fusarium oxysporum hyphae. J. Biol. Chem. 283, 14445-14452. doi: 10.1074/jbc.M709867200

Vandecandelaere, I., and Coenye, T. (2015). Microbial composition and antibiotic resistance of biofilms recovered from endotracheal tubes of mechanically ventilated patients. Adv. Exp. Med. Biol. 830, 137-155. doi: 10.1007/978-3-31911038-7_9

Vieira, M. E. B., Vasconcelos, I. M., Machado, O. L. T., Gomes, V. M., and Carvalho, A. O. (2015). Isolation, characterization and mechanism of action of an antimicrobial peptide from Lecythis pisonis seeds with inhibitory activity against Candida albicans. Acta Biochim. Biophys. Sin. 47, 716-729. doi: 10.1093/ abbs/gmv071

Viejo-Díaz, M., Andrés, M. T., and Fierro, J. F. (2004). Modulation of in vitro fungicidal activity of human lactoferrin against Candida albicans by extracellular cation concentration and target cell metabolic activity. Antimicr. Agents Chemother. 48, 1242-1248. doi: 10.1128/AAC.48.4.1242-1248. 2004

von Deuster, C. I. E., and Knecht, V. (2011). Competing interactions for antimicrobial selectivity based on charge complementarity. Biochim. Biophys. Acta 1808, 2867-2876. doi: 10.1016/j.bbamem.2011.08.005

Vriens, K. (2015). Mechanisms of Action of Antifungal Agents: Antibiofilm and Ion Channel Inhibitory Properties of Plant Defensins, and Single Cell Analysis of Amphotericin B-Induced Oxidative Stress. Dissertation. Leuven: University of Leuven.

Vriens, K., Cools, T. L., Harvey, P. J., Craik, D. J., Braem, A., Vleugels, J., et al. (2016a). The radish defensins RsAFP1 and RsAFP2 act synergistically with caspofungin against Candida albicans biofilms. Peptides 75, 71-79. doi: 10.1016/ j.peptides.2015.11.001

Vriens, K., Cools, T. L., Harvey, P. J., Craik, D. J., Spincemaille, P., Cassiman, D., et al. (2015). Synergistic activity of the plant defensin HsAFP1 and caspofungin against Candida albicans biofilms and planktonic cultures. PLoS One 10:e0132701. doi: 10.1371/journal.pone.0132701

Vriens, K., Kumar, P. T., Struyfs, C., Cools, T. L., Spincemaille, P., Kokalj, T., et al. (2017). Increasing the fungicidal action of amphotericin B by inhibiting the nitric oxide-dependent tolerance pathway. Oxid. Med. Cell. Longev. 2017, 4064628. doi: 10.1155/2017/4064628

Vriens, K., Peigneur, S., De Coninck, B., Tytgat, J., Cammue, B. P. A., and Thevissen, K. (2016b). The antifungal plant defensin AtPDF2.3 from Arabidopsis thaliana blocks potassium channels. Sci. Rep. 6:32121. doi: 10.1038/ srep32121

Vylkova, S., Li, X. S., Berner, J. C., and Edgerton, M. (2006). Distinct antifungal mechanisms: $\beta$-defensins require Candida albicans Ssa1 protein, while Trklp mediates activity of cysteine-free cationic peptides. Antimicrob. Agents Chemother. 50, 324-331. doi: 10.1128/AAC.50.1.324-331. 2006

Vylkova, S., Nayyar, N., Li, W., and Edgerton, M. (2007). Human $\beta$-defensins kill Candida albicans in an energy-dependent and salt-sensitive manner without causing membrane disruption. Antimicrob. Agents Chemother. 51, 154-161. doi: 10.1128/AAC.00478-06

Wachinger, M., Kleinschmidt, A., Winder, D., Von Pechmann, N., Ludvigsen, A., Neumann, M., et al. (1998). Antimicrobial peptides melittin and cecropin inhibit replication of human immunodeficiency virus 1 by suppressing viral gene expression. J. Gen. Virol. 79, 731-740. doi: 10.1099/0022-1317-79-4-731

Wang, G., Li, X., and Wang, Z. (2016). APD3: the antimicrobial peptide database as a tool for research and education. Nucleic Acids Res. 44, 1087-1093. doi: $10.1093 / \mathrm{nar} / \mathrm{gkv} 1278$

Wang, J., Xia, X. M., Wang, H. Y., Li, P. P., and Wang, K. Y. (2013). Inhibitory effect of lactoferrin against gray mould on tomato plants caused by Botrytis cinerea and possible mechanisms of action. Int. J. Food Microbiol. 161, 151-157. doi: 10.1016/j.ijfoodmicro.2012.11.025

Wilmes, M., Cammue, B. P. A., Sahl, H.-G., and Thevissen, K. (2011). Antibiotic activities of host defense peptides : more to it than lipid bilayer perturbation. Nat. Prod. Rep. 28, 1350-1358. doi: 10.1039/clnp00022e

World Health Organization [WHO] (2020). Antimicrobial Resistance. Geneva: World Health Organization.

Yount, N. Y., Kupferwasser, D., Spisni, A., Dutz, S. M., Ramjan, Z. H., Sharma, S., et al. (2009). Selective reciprocity in antimicrobial activity versus cytotoxicity of hBD-2 and crotamine. Proc. Nat. Acad. Sci. U.S.A. 106, 14972-14977. doi: 10.1073/pnas.0904465106

Yun, J. E., and Lee, D. G. (2016). Cecropin A-induced apoptosis is regulated by ion balance and glutathione antioxidant system in Candida albicans. IUBMB Life 68, 652-662. doi: 10.1002/iub.1527

Zasloff, M. (1987). Magainins, a class of antimicrobial peptides from Xenopus skin: isolation, characterization of two active forms, and partial cDNA sequence of a precursor. Proc. Nat. Acad. Sci. U.S.A. 84, 5449-5453. doi: 10.1073/pnas.84.15. 5449

Zasloff, M. (2002). Antimicrobial peptides of multicellular organisms. Nature 415, 389-395. doi: 10.1038/415389a

Conflict of Interest: The authors declare that the research was conducted in the absence of any commercial or financial relationships that could be construed as a potential conflict of interest.

Copyright (C) 2021 Struyfs, Cammue and Thevissen. This is an open-access article distributed under the terms of the Creative Commons Attribution License (CC BY). The use, distribution or reproduction in other forums is permitted, provided the original author(s) and the copyright owner(s) are credited and that the original publication in this journal is cited, in accordance with accepted academic practice. No use, distribution or reproduction is permitted which does not comply with these terms. 